\title{
補正エネルギー法による直線材構造物の弾塑性解析* \\ ELASTO-PLASTIC ANALYSIS OF FRAMES BY COMPLEMENTARY ENERGY METHOD
}

山崎徳 也**.太田俊 昭**.石川信 隆*** By Tokuya Yamasaki, Toshiaki Ōta and Nobutaka Ishikawa

\section{1. 緒言}

構造物の弾性解析においてエネルギー法を基礎として Castigliano の定理および最小仕事の原理などが導かれ， これより 3 連および 4 連モーメントの定理やたわみ角法 あるいはモーメント分配法など構造力学において久くべ からざる理論の大半が導き出されたことは周知のとおり である。他方塑性分野においても補正エネルギーを用い た “Complementary Minimum Principle” が A. Nadai $^{1)}$, H.M. Westergard ${ }^{2)}$, E.H. Brown ${ }^{3)}$, B. Rawlings ${ }^{4)}$ ，Langhaor ${ }^{5)}$ などによって原理的に証明され， これに基づくエネルギー法がそれぞれ提案されている が，いまだ弾性のごとくこの原理のもつ普遍性と簡易性 とを十分に生かして広く実用に供せしめる域までには至 っていない。このことは塑性領域における補正エネルギ 一を厳密に求める場合，式型が複雑な非線型となるうえ に断面形状によって関数形が異なるゆえ，その後の演算 がきわめて繁雑となり実用上その意義を失うことに由来 する。

本論文は上記難点を排除した補正エネルギーの実用式 を導き, 変分原理を適用して構造物の弹塑性解析に関す る理論体系の確立とその実用化とを試みたもので，第 1 段階として最も代表的な直線材構造物の弾塑性挙動を論 じた。

直線材を対象とする弾塑性応力解析に関する既往の研 究には, $M-\phi$ 関係の塑性域を忠実に曲線と見做した K.H. Gerstle ${ }^{6)}$ やR.J.P. Gerden ${ }^{7)}$, K.E. Knudsen 他 ${ }^{8)}$ などの精密解析があるが，前述したごとく関数が非線 型であるため特殊の問題に限定せざるをえず，また鉄筋 コンクリート材を対象とし弾性曲線の微分 方程式よりたわみ角式を誘導した山田氏9 の研究は，弾塑性境界におけるたわみとた わみ角の連続条件より積分定数を逐次決定 すべき繁雑さに加えて，対象が一様断面の 直線ばりに限られ，また部材の途中に塑性 領域が生ずる場合の取り扱いや荷重項の算 出も容易でないなどの難点があげられる。

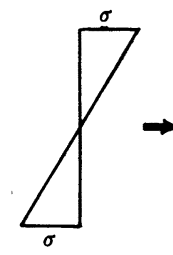

(a) 弾性

* 昭和 39 年 5 月第 19 回土木学会年次学術講演会にて一部 発表済

** 正 会 員 工博 九州大学教授 工学部土木教室

*** 学生会員 工修 九州大学大学院工学研究科土木工学専攻

**** 学生会員 工修 九州大学大学院工学研究科土木工学専攻

既往研究とは異なり，著者らははりの断面に生ずる弾 塑性応力分布ならびにひずみ分布を用いて単位長さ当り の断面に貯えられる補正エネルギーを厳密に算定し，そ の非線型要素を除くべく塑性領域における $M-\phi$ 曲線を $M-\phi$ 近似直線で置換したうえで，同近似直線に基ゔき 任意断面，任意荷重に適用しうる普遍的な実用補正エネ ルギー式を理論的に誘導し,変分原理すなわち Complementary Minimum Principle を適用して静定ばりの弾 塑性挙動に対する基本的考察を行ない，精度の吟味を行 なって実用性を確認し, さらに弾塑性領域を考慮した直 線材たわみ角式を導き, 弾性解析におけるたわみ角法と 同一手法で不静定構造物の弾塑性解析を可能ならしめ, 加えて各係数を数表化して実用に供しうるごとくした。

\section{2. 曲げモーメントと曲率との関係}

本論文では塑性解析での慣用にしたがってつぎのごと き仮定を採用した。

（i）応力一ひずみ関係は 図一1のごとく静的降伏点 $\sigma_{y}$ に達するまで弾性で, $\sigma_{y}$ に達したのちは一定応力 $\sigma_{y}$ のもとに無制限塑 性流れを生ずる。 ただし履歴効果は ないものとする。

(ii) 平面保持 の法則にしたがっ て微小曲率を取り 扱う。

(iii) 圧縮側の 応力ーひずみ関係

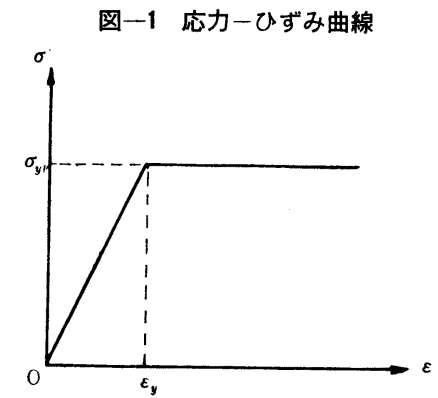

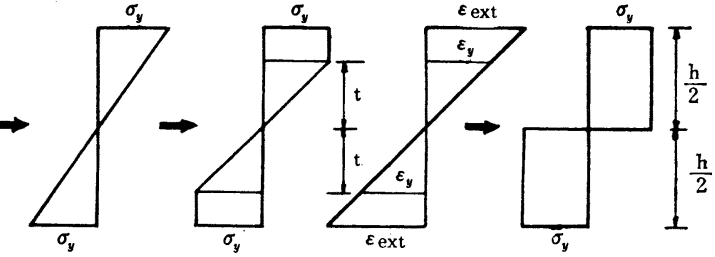

(b) 弾性限界 (c) 弾塑性
ひずみ分布

は引張側と同一と見做す。

いま漸増曲げモーメントを受けた長方形断面ばりの断 面に生ずる応力分布を，上記仮定に基づいて弾性より弾 塑性状態を経て完全塑性状態に至る全過程について示せ 
ば図一2 のごとくなり，弾性ならびに弾塑性状態におけ る曲げモーメントと曲率との関係はそれぞれつぎのごと く求められる。

すなわち 図一2（a）の弾性状態では曲げモーメント を $M$, 曲げ剛性を $E I$ とすれば, 曲率 $\phi$ は周知のごと く Hooke の法則によって次式となる。

$$
\phi=\frac{M}{E I}
$$

つぎに 図一2 (b) のごとく外縁が降伏応力 $\sigma_{y}$ に達し たとき, 式 (1) は $\phi=\phi_{y}\left(=M_{y} / E I\right)$ なる弾性限界に おけ萧率を与える。ここに $M_{y}$ は降伏曲げモーメント で次式で示される。

$$
M_{y}=b h^{2} \sigma_{y} / 6=2 I \sigma_{y} / h
$$

ただし， $b$ および $h$ は長方形断面の幅および高さを 示す。

一方図-2 (c) の弾塑性状態では弾性領域の深さを $2 t$ とすれば, 曲げモーメント $M$ はつぎのごとく求められ る。

$$
\begin{aligned}
M & =\int \sigma y d A=2 \int_{t}^{h / 2} \sigma_{y} y b d y+2 \int_{0}^{t} \sigma y b d y \\
& =\left(\frac{h^{2}}{4}-\frac{t^{2}}{3}\right) b \sigma_{y} \ldots \ldots \ldots \ldots \ldots \ldots \ldots \ldots \ldots \ldots \ldots \ldots \ldots \ldots \ldots \ldots
\end{aligned}
$$

しかるに曲率 $\phi$ は $\phi=\varepsilon_{y} / t=\sigma_{y} / E t$ となり, 上式に代 入して $t$ を消去すれば, 結局弾塑性状態における曲げモ ーメントと曲率との関倸がつぎのごとくえられる。

$$
M=\frac{3}{2} M_{y}\left[1-\frac{1}{3}\left(\frac{\phi_{y}}{\phi}\right)^{2}\right] \ldots
$$

式 (2b) の $\phi$ を無限大とすれば, 曲げモーメントは $M=3 M_{y} / 2=M_{p}$ となり, 図一2 (d) のごとく全断面の 応力が降伏に至ったときのいわゆる塑性曲げモーメント を表わす。

以上の考察より 図一3 のごとき $M-\phi$ 曲線が求めら れ, $\mathrm{OA}$ 直線が式 (1) に, $\mathrm{AB}$ 曲線が式 $(2 \mathrm{~b})$ に該当 する。なお式 $(2 \mathrm{~b})$ は $M$ を変数としてつぎのごとく変 形される。

$$
\phi=\frac{\phi_{y}}{\sqrt{3-2 M / M_{y}}}
$$

图一-3 $M-\phi$ 曲線

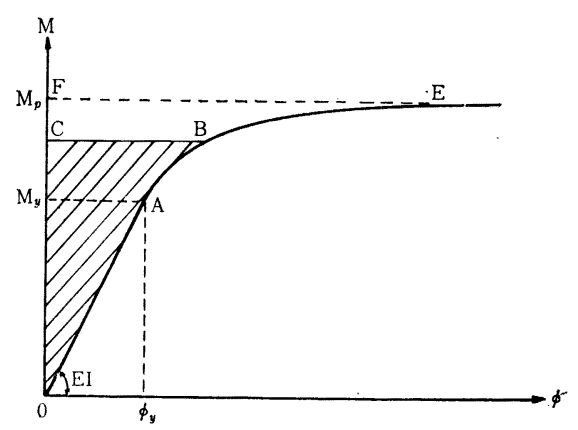

\section{3. 補正エネルギーの実用式}

一般に，曲げ応力によって生ずる単位長さ当りの断面 に貯えられる補正エネルギーは次式で与えられる。

$$
\frac{\partial U}{\partial S}=\int_{A} \int_{\sigma} \varepsilon d \sigma d A
$$

いま中立軸より距離 $y$ にある微小断面 $\Delta A$ に作用す る応力 $\sigma$ によって生ずる微小曲げモーメントは $\Delta M=$ $\sigma y \Delta A$ となり, これを応力 $\sigma$ で偏微分すれば $\Delta M$ の 変化量 $d(\Delta M)$ がつぎのごとく求められる。

$$
d(\Delta M)=\frac{\partial(\sigma y \Delta A)}{\partial \sigma} d \sigma=y \Delta A d \sigma=\frac{\varepsilon}{\phi} \Delta A d \sigma
$$

上式を全断面について加算したうえで $\Delta A$ を無限小 にすれば,

$$
\lim _{\Delta M \rightarrow 0} \Sigma d(\Delta M)=\lim _{\Delta A \rightarrow 0} \Sigma \frac{\varepsilon}{\phi} \Delta A d \sigma
$$

しかるに $\phi$ は断面において一定で $y$ に無関係なるゆ え，上式は結局つぎのごとくなる。

$$
\begin{aligned}
& \phi d M=\int_{A} \varepsilon d \sigma d A \\
& \text { よって式 ( } 3 \text { ) より } \\
& \frac{\partial U}{\partial S}=\int_{A} \int_{\sigma} \varepsilon d \sigma d A=\int_{M} \phi d M
\end{aligned}
$$

すなわち式 (4) は“単位長さ当りのはりの断面に貯 えられる補正エネルギーが 図一3 のごとく $M-\phi$ 曲線 の斜線部の面積 $\mathrm{OABC}$ で与えられる”。という一般原 理を裹づけるものである。

したがって式 (4) に式 (1) および式 (2c) を代入 すれば, 長方形断面ばりに対する補正エネルギーがただ ちに算定され次式となる。

弾性領域においては,

$$
\frac{\partial U}{\partial S}=\frac{M^{2}}{2 E I}
$$

弹塑性領域においては,

$$
\begin{aligned}
\frac{\partial U}{\partial S} & =\int_{0}^{M_{y}} \frac{M}{E I} d M+\int_{M_{y}}^{M} \frac{\phi_{y} d M}{\sqrt{3-2 M / M_{y}}} \\
& =\frac{M_{y}{ }^{2}}{2 E I}\left[3-2 \sqrt{3-2 M / M_{y}}\right] \cdots \cdots \cdots
\end{aligned}
$$

式 (5) および式 (6) をはりの長さ方向について積 分すれば，弾塑性領域を考慮した長方形断面ばりに対す る厳密補正エネルギー式がつぎのごとくえられる。

$$
U=\int_{E} \frac{M^{2}}{2 E I} d S+\int_{P} \frac{M_{y}^{2}}{2 E I}\left(3-2 \sqrt{3-2 M / M_{y}}\right) d S
$$

ここに積分記号の添字 $E$ および $P$ はそれぞれはりの 外縁面での弹性領域および塑性領域の長さを示す。

一般に補正エネルギー式は断面形状によって関数形が 異なり，しかもきわめて複雑な式型となり，最も簡単な 長方形断面の場合でも式 ( 7 ) のごとくで, その後の取 り扱いが相当困難である。 $M-\phi$ 曲線は図一3 に示すご 
図-4 M- $\phi$ 第 1 近似直線

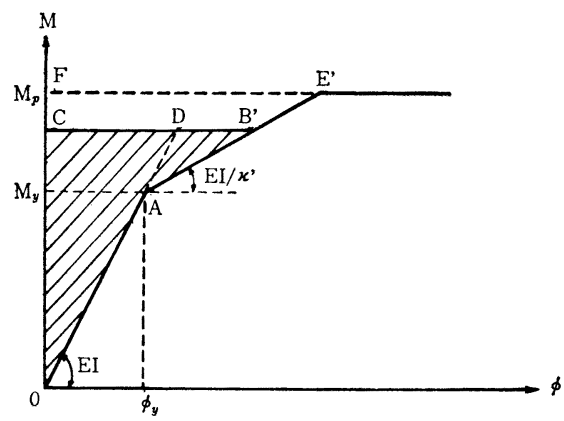

とく弾性領域では直線で, 塑性領域では曲線となり, $M$ が $M_{P}$ に近づくにつれ $M=M_{P}$ の直線に漸近する。こ の曲線部を忠実に追跡することが非線型の主要因を形成 するゆえ, これを排除するため図一4 のごとく近似的に 直線で置き換えたうえで, 式 (4) に基づいて補正エネ ルギー $\partial U / \partial S$ を同図の斜線部の面積 $\mathrm{OAB}^{\prime} \mathrm{DC}$ で算 定する。

すなわち $M-\phi$ 近似直線の勾配を $E I / \kappa^{\prime}$ とすれば, 弾 塑性領域における曲率 $C B^{\prime}$ は $\phi=\kappa^{\prime}\left(M-M_{y}\right) / E I+\phi_{y}$ となり, 斜線部の面積はつぎのごとくなる。

面積 $O A B^{\prime} D C=\triangle O D C+\triangle A B^{\prime} D$

$$
=\frac{M^{2}}{2 E I}+\frac{M-M_{y}}{2}\left(\phi-\frac{M}{E I}\right)
$$

したがって弾塑性領域における単位長さ当りの補正エ ネルギーはつぎの式 ( 8 ) のごとく簡単な $M$ の 2 次式 で表わされ, 部材全体にわたる補正エネルギーの実用式 が弾性ならびに弾塑性領域を考慮した式 (9) にて求め られることになる。

$$
\begin{aligned}
& \frac{\partial U}{\partial S}=\frac{1}{2 E I}\left[M^{2}+\left(\kappa^{\prime}-1\right)\left(M-M_{y}\right)^{2}\right] \cdots(8) \\
& U=\int_{E+P} \frac{M^{2}}{2 E I} d S+\kappa \int_{P} \frac{\left(M-M_{y}\right)^{2}}{2 E I} d S \cdots(9)
\end{aligned}
$$

ただし $\kappa=\kappa^{\prime}-1$

ここで， $M-\phi$ 近似直線の勾配を表わす $\kappa^{\prime}$ は “ $M$ が $M_{P}$ に達したとき， $M-\phi$ 近似直線による補正エネルギ 一が $M-\phi$ 曲線によるそれと同值でなければならない”。 という置換条件より算定される。したがって図一3の面 積 $\mathrm{OABEF}$ と図一4 の面積 $\mathrm{OAB}^{\prime} \mathrm{E}^{\prime} \mathrm{F}$ とを等置して $\kappa^{\prime}$ を決定する。前者の面積を $A_{C}$, 後者の面積を $A_{S}$ とす れば式 (6) および式 (8) において $M=M_{P}=3 M_{y} / 2$ としてそれぞれつぎの值をうる。

$$
A_{C}=\frac{3 M_{y}^{2}}{2 E I}, \quad A_{S}=\frac{M_{y}^{2}}{8 E I}\left(8+\kappa^{\prime}\right)
$$

よって $A_{C}=A_{S}$ とすれば長方形断面では $\kappa^{\prime}=4$, した がって $x=3$ と決定される。

さらに他形状の断面について考察すれば, 単に式

\begin{tabular}{|c|c|c|c|c|c|}
\hline $\begin{array}{c}\text { 断面 } \\
\text { 形状 } \\
\text { 定 } \\
\text { 数 } \\
\end{array}$ & $\left.\forall I D\right|^{n}$ & 10 & 89 & $\underbrace{1}_{b \rightarrow 1}$ & 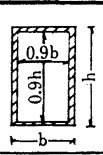 \\
\hline $\begin{array}{l}\mathrm{f}= \\
\mathrm{M}_{\mathrm{p}} / \mathrm{M}_{\mathrm{y}}\end{array}$ & 1.500 & 1.140 & $1.700^{\circ}$ & 2.000 & 1.182 \\
\hline$\overline{\mathrm{f}}=$ & 1.250 & 1.066 & 1.307 & 1.500 & 1.064 \\
\hline $\boldsymbol{x}^{\prime}$ & 4.000 & 9.792 & 3.300 & 3.000 & 8.855 \\
\hline$x$ & 3.000 & 8.792 & 2.300 & 2.000 & 7.855 \\
\hline $\boldsymbol{x}_{i}^{\prime}$ & 1.376 & 1.373 & 1.200 & 1.084 & 1.338 \\
\hline$\kappa_{1}$ & 0.376 & 0.373 & 0.200 & 0.084 & 0.338 \\
\hline$x_{i}^{\prime}$ & 11.872 & 33.242 & 7.753 & 8.766 & 20.388 \\
\hline$x_{2}$ & 10.496 & 31.869 & 6.553 & 7.682 & 19.050 \\
\hline
\end{tabular}
(2b) および式（6）のみが変わり，したがって算出さ れる $\kappa$ 值が 表一1 のごとくそれぞれ異なった定数とな
表-1

るが，補正エネルギーの式表現は不変で, 式 (9)によ る一般表示が可能となる。よって本法によれば断面形状 による難易も問題とならず，あらかじめ $\kappa$ を算出してお けばすべての断面形状を含みうる一般性は大きな特色と いえ，その実用性を強調しうるものである。

以上 1 本の近似直線 ( $M-\phi$ 第 1 近似直線と名付ける) による補正エネルギーの実用式を誘導したが，さらに精 度をあげるためには塑性領域における $M$ - $\phi$ 曲線を図一5 のごとき $n$ 本の折線で近似すればよい。ここで折線は連 続条件のほかに, 前記エネルギー等置の条件によって決 定される。しかし $n$ を多くすれば精度は増すが, 反面実 用性が失われ， $n$ の決定について種々計算例によって検 討した結果 ${ }^{10)}$ ，つぎのことが明らかとなった。 いま断面の形状係数を $f=M_{P} / M_{y}$ とすれば,

图一5

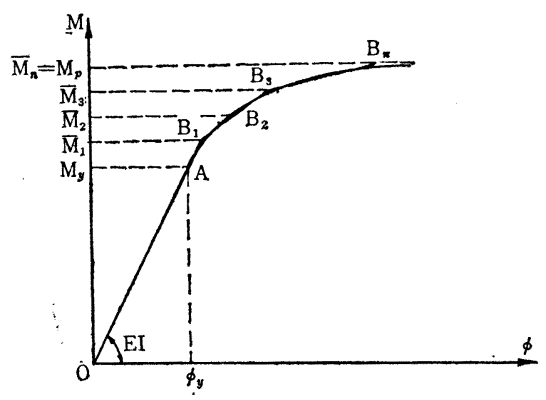

図一6 $M-\phi$ 第 2 近似直線

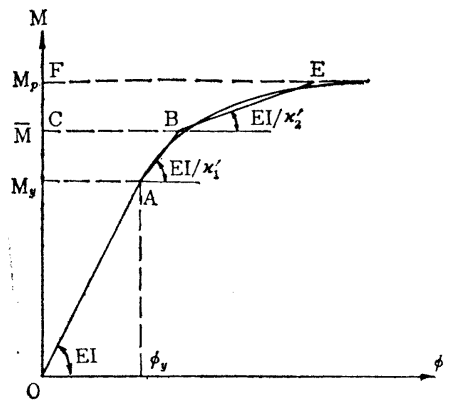


(1) $f \leqq 1.5$ の薄肉断面 ( I 形, 箱形, 長方形) に 対しては $n=1$ で十分である。

(2) $f \geqq 1.5$ の太肉断面 (長方形, 円形, ダイヤモ ンド形）に対しては $n=2$ までを考える。

ここで 図-6 のごとき $n=2$ の $M-\phi$ 第 2 近似直線に 対する補正エネルギーを式 (9) と同様の手法で算定す れば次式をうる。

$$
\begin{aligned}
U= & \int_{E+P_{1}+P_{2}} \frac{M^{2}}{2 E I} d S+\kappa_{1} \int_{P_{1}+P_{2}} \frac{\left(M-M_{y}\right)^{2}}{2 E I} d S \\
& +\kappa_{2} \int_{P_{2}} \frac{(M-\bar{M})^{2}}{2 E I} d S \cdots \cdots \cdots \cdots \cdots \cdots \cdots(10)
\end{aligned}
$$

ここに, $\kappa_{1}=\kappa_{1}{ }^{\prime}-1, \kappa_{2}=\kappa_{2}{ }^{\prime}-\kappa_{1}{ }^{\prime}$, また積分記号の添字 $P_{1}$ および $P_{2}$ はそれぞれはり外縁面での第 1 塑性領域 $\left(M_{y} \leqq M \leqq \bar{M}\right)$ および第 2 塑性領域 $\left(\bar{M} \leqq M \leqq M_{P}\right)$ の長さを示す。 $\bar{M}$ を臨界曲げモーメントと名付け, $\bar{M}=\left(M_{P}+M_{y}\right) / 2$ を主体として 表一1 のごとき值を採 用した。なお $M-\phi$ 第 2 近似直線の勾配を決定する $\kappa_{1}{ }^{\prime}$, $\kappa_{2}{ }^{\prime}$ の值は前記エネルギー等置の条件により, 各断面に 対して表一1 のごとく算定される。

\section{4. 補正エネルギー法}

Complementary Minimum Principle とは“系が真 の平衡状態にあるとき, 全補正ポテンシャルは応力の変

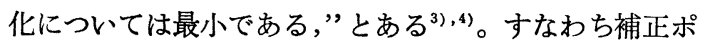
テンシャルおよび外力による補正仕事をそれぞれ $U, W$ とすれば次式が成立する。

$$
\begin{aligned}
& d(U-W)=0 \\
& \text { よって } \\
& d U-d W=0 . .
\end{aligned}
$$

いま理解に便ならしめるため 図一7 のごとき単純ばり について考察を行なえば, $P_{i}(i=1,2, \cdots)$ の変化 $d P_{i}$ $(i=1,2, \cdots)$ による補正エネルギーの変化は

$$
d U=\sum_{i} \frac{\partial U}{\partial P_{i}} d P_{i}
$$

一方外力による補正仕事の変化も図一7を参照して

$$
d W=\sum_{i} \delta_{i} d P_{i}
$$

式 (11) に式 (12) および式 (13) を代入すれば

$$
\sum_{i}\left(\frac{\partial U}{\partial P_{i}}-\delta_{i}\right) d P_{i}=0
$$

$d P_{1}, d P_{2}, \cdots, d P_{i}, \cdots$ はそれぞれ独立であるから

$$
\delta_{i}=\frac{\partial U}{\partial P_{i}}
$$

図-7

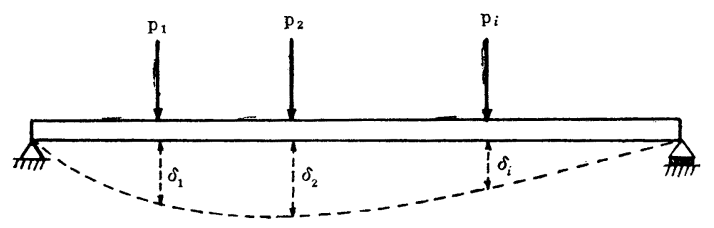

もちろん変位に力が対応するごとく回転角に曲げモー メントが対応し次式が成立する。

$$
\theta_{i}=\frac{\partial U}{\partial M_{i}}
$$

式 (14)，(15）と式（9），(10）とを併用することに よって, 長方形断面さらには任意の断面について弹塑性 領域を考慮した最小仕事の原理などの変分法が成立可能 となり, 実際解法としての弾塑性領域を考慮した 3 連お よび 4 連モーメントの定理や 7. で述べるたわみ角式が 誘導でき, しかもその手法は弾性解析の場合と全く同様 である。

なお塑性領域を考虑したたわみの算定法には C.H. Yang の $\phi$-Area Method ${ }^{8}$ やW.H. Weiskopf ${ }^{8)}$ の弾 性曲線に基づく厳密解法などがあるが, 中でも $\phi-A r c a$ Method は本エネルギー法を用いることにより容易に誘 導可能となる。

すなわちモーメント $M$ は一般に $M=f(\phi)$ で表わさ れ, $d M=f^{\prime}(\phi) d \phi$ となるゆえ, 式 (4) に代入したう えで $d S$ で積分すれば, 補正エネルギー $U$ はつぎのご とくなる。

$$
U=\iint \phi f^{\prime}(\phi) d \phi d S
$$

よって式 (14) および式 (15) を上式に適用すれば, 変位 $\delta_{i}$ および回転角 $\theta_{i}$ の算定式として次式が導かれ る。

$$
\begin{aligned}
& \delta_{i}=\frac{\partial U}{\partial P_{i}}=\int\left(\phi f^{\prime}(\phi) \cdot \frac{1}{f^{\prime}(\phi)} \cdot \frac{\partial M}{\partial P_{i}}\right) d S \\
& =\int \phi \frac{\partial M}{\partial P_{i}} d S \text {. }
\end{aligned}
$$

同様に

$$
\theta_{i}=\frac{\partial U}{\partial M_{i}}=\int \phi \frac{\partial M}{\partial M_{i}} d S
$$

いま図一8 のごとき両端 $\mathrm{A}, \mathrm{B}$ にそれぞれ外力モーメ ント $M_{A}, M_{B}$ が働く単純ばり $\mathrm{AB}$ を想定し, 任意点 Cが一般に荷重点でないとすれば仮想荷重および仮想モ ーメントとしてそれぞれ $P_{C}$ および $M_{C}$ を作用させて,

図-8

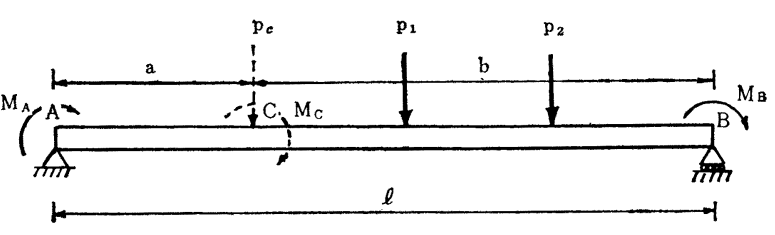

$\mathrm{C}$ 点のたわみ $\delta_{C}$ およびたわみ角 $\theta_{C}$ を以下のごとく 求めうる。

任意点のモーメント $M$ は実際外力荷重によるモー メントを $M_{0}$ として

$\mathrm{A} \sim \mathrm{C}$ 間において, 


$$
\begin{aligned}
& M_{1}=\frac{l-x}{l} M_{A}-\frac{x}{l} M_{B}-\frac{x}{l} M_{C}+\frac{P_{C} b}{l} x+M_{0} \\
& \text { よって } \\
& \frac{\partial M_{1}}{\partial P_{C}}=\frac{b}{l} x \\
& \mathrm{C} \sim \mathrm{B} \text { 間において, } \\
& \text { よって } \\
& \begin{aligned}
M_{2}= & \frac{l-x}{l} M_{A}-\frac{x}{l} M_{B}+\frac{l-x}{l} M_{C} \\
& +\frac{P_{c} a}{l}(l-x)+M_{0}
\end{aligned} \\
& \frac{\partial M_{2}}{\partial P_{C}}=\frac{a}{l}(l-x) \\
& \delta_{C}=\int_{0}^{a} \phi \frac{b}{l} x d x+\int_{a}^{l} \phi \frac{a}{l}(l-x) d x \\
& =\int_{0}^{l} \phi \frac{a}{l}(l-x) d x-\int_{0}^{a} \phi(a-x) d x \\
& \int_{0}^{l} \phi(l-x) d x / l=\theta_{A}
\end{aligned}
$$

で，上式の第 1 項に適用し，さらに支点 $\mathrm{A}$ のたわみ $\delta_{A}$ がある場合にはこれを加味して結局次式がえられる。

$$
\delta_{C}=\delta_{A}+a \theta_{A}-\int_{0}^{a} \phi(a-x) d x
$$

同様にたわみ角 $\theta_{C}$ は式 (17) において $i=C$ とおけ ば,

$$
\begin{aligned}
& \theta_{C}=\int_{0}^{a} \phi\left(-\frac{x}{l}\right) d x+\int_{a}^{l} \phi\left(\frac{l-x}{l}\right) d x \\
& =\theta_{A}-\int_{0}^{a} \phi d x
\end{aligned}
$$

すなわち式 (18) および式 (19) は $\phi$-Area Method の公式と完全に合致する。このことは取りも直さず $\phi-$ Area Method がエネルギー法の特例として包含されう ることを意味するものであり，本法の一般性をここに強 調しうるものである。

\section{5. せん断の影響について}

前記補正エネルギー式の誘導に当っては，せん断力の 影響を無視したので，本節ではせん断力の補正エネルギ 一におよぼす効果について理論的考察ならびに数值的吟 味を行ない, 前記仮定の妥当性を検討する。

弾塑性状態における曲げ応力 $\sigma$ およびせん断応力 $\tau$ の分布は, 塑性理論 ${ }^{11}$ によれば 図一9 のごとくなり, せ ん断応力 $\tau$ は次式で与えられる。

$$
\tau=\tau_{1}\left(1-\frac{y^{2}}{t^{2}}\right), \quad|y| \leqq t
$$

ただし, $\tau_{1}:$ 定数

よってせん断力 $Q$ は断面を長方形と 見なせばつぎの ごとくなる。

$$
Q=\int \tau d A=\tau_{1} \int_{-t}^{t} b\left(1-\frac{y^{2}}{t^{2}}\right) d y=\frac{4}{3} \tau_{1} b t
$$

图一9

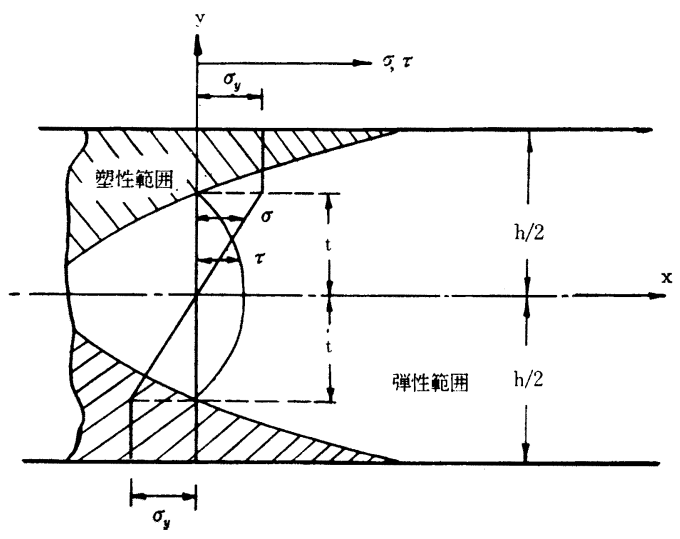

応力の降伏状態が進行し, 中立軸のせん断応力が Mises の降伏条件により $\tau=\sigma_{y} / \sqrt{3}$ に達すると, せん断 核が生起していわゆる塑性ヒンジが形成される。

すなわち式 (20) および式 (21) より

$$
Q_{P}=\frac{4}{3} \cdot \frac{\sigma_{y}}{\sqrt{3}} b t
$$

よって純降伏せん断力 $Q_{y}=2 \sigma_{y} b h / 3 \sqrt{3}$ で上式の両 辺を割れば，

$$
\frac{Q_{P}}{Q_{y}}=2\left(\frac{t}{h}\right)
$$

一方このときのモーメントを $M_{P Q}$ とすれば式 $(2 \mathrm{a})$ より,

$$
M_{P Q}=\frac{b h^{2}}{12} \sigma_{y}\left\{3-4\left(\frac{t}{h}\right)^{2}\right\}
$$

式（22）を上式に代入し $M_{\boldsymbol{y}}$ で両辺を割れば, 結局完 全塑性状態における曲げモーメントとせん断力との相関 関係が次式でえられる。

$$
\frac{M_{P Q}}{M_{y}}=\frac{3}{2}\left[1-\frac{1}{3}\left(\frac{Q_{P}}{Q_{y}}\right)^{2}\right]
$$

つぎに弾塑性状態時のせん断応力によって生ずる単位 長さ当りの補正エネルギーを算定すればつぎのごとくで ある。

$$
\frac{\partial U}{\partial S}=\int_{A} \int_{\tau} r d \tau d A=\int_{A} \frac{\tau^{2}}{2 G} d A
$$

式（24）に式（20）を代入して $y$ について積分すれ ば,

$$
\frac{\partial U}{\partial S}=b \int_{-t}^{t} \frac{\tau^{2}}{2 G}\left(1-\frac{y^{2}}{t^{2}}\right)^{2} d y=\frac{8 b}{15 G} \tau_{1}{ }^{2} t
$$

また式 (21) および式 (2a) を用いて $\tau_{1}$ および $t$ を消 去すれば次式となる。

$$
\frac{\partial U}{\partial S}=\frac{3 Q^{2}}{5 G A} \frac{1}{\sqrt{3-2 M / M_{y}}}
$$

よってはり全体に貯えられるせん断補正エネルギー $U_{Q}$ は, 弾性領域も考虑して結局次式で与えられる。

$$
U_{Q}=\alpha \int_{E} \frac{Q^{2}}{2 G A} d S+\alpha \int_{P} \frac{Q^{2}}{2 G A} \frac{d S}{\sqrt{3-2 M / M_{y}}}
$$


ただし， $\alpha=1.2$ (長方形断面の場合)

したがって曲げモーメントおよびせん断力の影響を考 慮した厳密補正エネルギー $U_{M+Q}$ は式 (7) および式 (26) より次式でえられる。

$$
\begin{aligned}
U_{M+Q}= & U_{M}+U_{Q}=\int_{E} \frac{M^{2}}{2 E I} d S \\
& +\int_{P} \frac{M_{y}^{2}}{2 E I}\left(3-2 \sqrt{3-2 M / M_{y}}\right) d S \\
& +\alpha \int_{E} \frac{Q^{2}}{2 G A} d S \\
& +\alpha \int_{P} \frac{Q^{2}}{2 G A} \cdot \frac{d S}{\sqrt{3-2 M / M_{y}}} \cdots \cdots(27)
\end{aligned}
$$

以上の考察に基づいてせん断力の影響を数值的に把握 するため, 単純ばりの中央点に集中荷重 $P$ が作用する 場合のたわみの算定を行なってみる。

いま図一10のごとく中央に塑性領域が $2 b_{1}\left(=l-2 a_{1}\right)$ だけ生ずるものとすれば，任意点の曲げモーメントおよ びせん断力は $\mathrm{A} \sim \mathrm{C}$ 間で $M=P x / 2$ および $Q=P / 2$ と なり, せん断力のみによるたわみ $\delta_{Q}$ および曲げモーメ

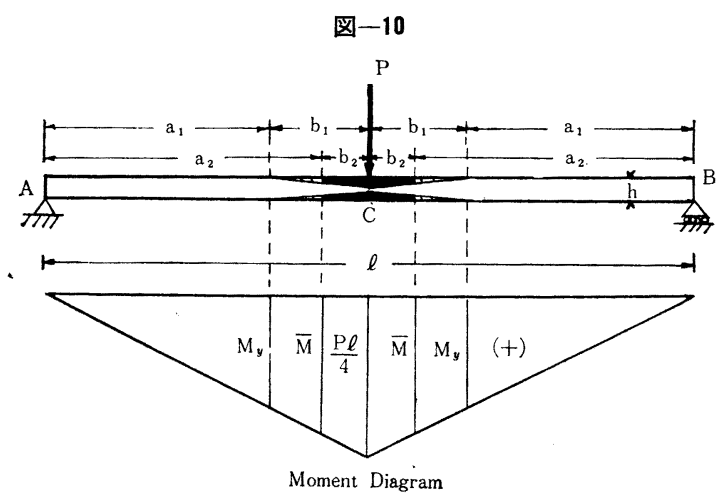

ントをも考慮したたわみ $\delta_{M+Q}$ は，それぞれ式 (14) に 式 (26) および式 (27) を適用してつぎのごとく求めら れる。

$$
\begin{aligned}
\delta_{\theta}= & {\left[\alpha \int_{0}^{a_{1}} \frac{Q}{G A} \frac{\partial Q}{\partial P} d x\right.} \\
+ & \alpha \int_{a_{1}}^{l / 2}\left(\frac{Q}{G A} \frac{1}{\sqrt{3-2 M / M_{y}}} \cdot \frac{\partial Q}{\partial P}\right. \\
+ & \left.\frac{Q^{2}}{2 G A} \frac{1}{\sqrt{\left(3-2 M / M_{y}\right)^{3}}} \cdot \frac{\partial M}{\partial P}\right) d x \\
= & \frac{\alpha P a_{1}}{2 G A}[2-\sqrt{3-l / a} \\
+ & \left.\frac{P a_{1}}{4 M_{y}}\left(\frac{3-l / 2 a_{1}}{\sqrt{3-l / a_{1}}}-2\right)\right] \\
\delta_{M+Q}= & 2\left[\int_{0}^{a_{1}} \frac{M}{E I} \frac{\partial M}{\partial P} d x\right. \\
& \left.+\int_{a_{1}}^{l / 2} \frac{M M_{y}}{E I} \cdot \frac{1}{\sqrt{3-2 \bar{M} / M_{y}}} \frac{\partial M}{\partial P} d x\right]+\delta_{Q} \\
= & \frac{P a_{1}{ }^{3}}{6 E I}+\frac{M a_{y} a_{1}{ }^{2}}{2 E I} \\
& \times\left[\frac{8}{3}-\left(2+\frac{l}{3 a_{1}}\right) \sqrt{3-\frac{l}{a^{1}}}\right]+\delta_{Q}
\end{aligned}
$$

さらに弾塑性境界条件 $M_{x=a_{1}}=P a_{1} / 2=M_{y}$ より $a_{1}=$ $2 M_{y} / P$ をえ, また降伏曲げモーメント $M_{\boldsymbol{y}}$ を初期降伏 荷重 $P_{0}$ で示せば $M_{y}=P_{0} l / 4$ となるゆえ, これらを式 （28）に代入すれば結局たわみが荷重比 $\boldsymbol{P}=P / P_{0}$ の関数 として表示され次式となる。

$$
\begin{aligned}
\delta_{\boldsymbol{Q}}= & \left(\frac{M_{y} l^{2}}{12 E I}\right)\left(\frac{E}{G}\right)\left(\frac{h}{l}\right)^{2} \\
& \times\left[1-\sqrt{3-2 \boldsymbol{P}}+\frac{1}{2}\left(\frac{3-\boldsymbol{P}}{\sqrt{3-2 \boldsymbol{P}}}\right)\right]
\end{aligned}
$$

図-11

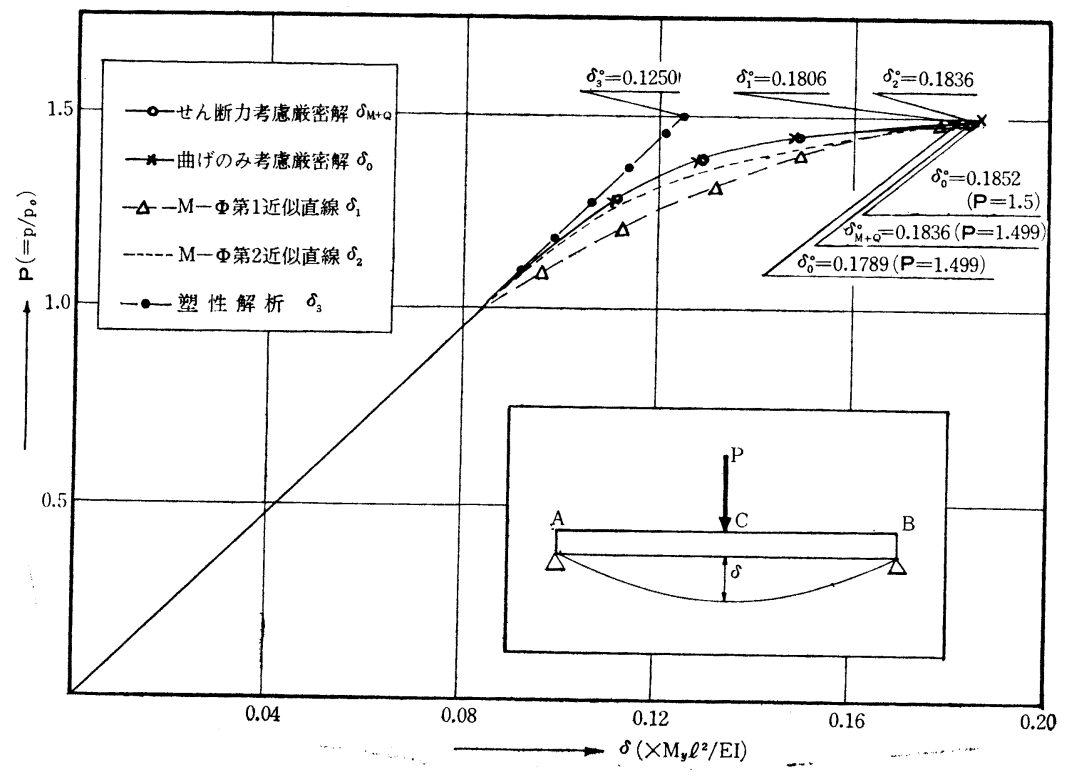




$$
\begin{aligned}
\delta_{M+Q}= & \left(\frac{M_{y} l^{2}}{12 E I}\right)\left(\frac{1}{\boldsymbol{P}}\right)^{2} \\
& \times[5-(\boldsymbol{P}+3) \sqrt{3-2 \boldsymbol{P}}]+\delta_{\boldsymbol{Q}}
\end{aligned}
$$

一方崩壊荷重 $P_{P}$ は式 (23) より次値となる。

$$
P_{P}=\frac{3}{\sqrt{1+K}+1} P_{0}
$$

ただし $, K=\frac{9}{4}\left(\frac{h}{l}\right)^{2}, \quad P_{0}=4 \frac{M_{y}}{l}$

したがって弾塑性時の $P$ 值の範囲は上限が崩壊荷重 $P_{P}$ で, 下限が初期降伏荷重 $P_{0}$ と規定される。すなわ ち,

$$
P_{0} \leqq P \leqq P_{P}
$$

$P$ を上記範囲にとり，式 $(29)$ の $\delta_{M+Q}$ を $h / l=0.03$ に対して算定すれば 図一11 のごとくなり，また誤差が 最大となる崩壊荷重 $P_{P}$ における $\delta_{Q}{ }^{\circ}$ および $\delta M_{M} Q^{\circ}$ を, 通常使用される部材として $h / l=0.02 \sim 0.05$ について算 出した結果は表-2 に示したごとくで, $\delta_{Q} \% \delta_{M+Q}{ }^{\circ} \times 100$ \% は高々 2〜5\% に止り，さらに片持ばりに対しても同

\begin{tabular}{|c|c|c|c|c|}
\hline \multicolumn{5}{|c|}{ 表-2 } \\
\hline$h / l$ & 0.02 & 0.03 & 0.04 & 0.05 \\
\hline & 173.2 & 115.5 & 86.6 & 69.3 \\
\hline $\begin{array}{c}\delta \\
\left(\times M_{y} l^{2} / E I\right)\end{array}$ & 1.4997 & 1.4992 & 1.4987 & 1.4979 \\
\hline$\delta_{Q^{\circ}}$ & $0.3105 \times 10^{-2}$ & $0.4733 \times 10^{-2}$ & $0.6409 \times 10^{-2}$ & $0.8134 \times 10^{-2}$ \\
\hline$\delta_{M+Q^{\circ}}$ & 0.1840 & 0.1836 & 0.1833 & 0.1830 \\
\hline$\frac{\delta_{Q^{\circ}}}{\delta_{M+Q^{\circ}}} \times 100 \%$ & $1.7 \%$ & $2.5 \%$ & $3.5 \%$ & $4.4 \%$ \\
\hline
\end{tabular}
様の結果をえ, 以上より $h / l=0.05$ より細長い部材（細 長比 $i \geqq 70)$ ではせん断力を無視した補正エネルギー式 の使用が十分容認される。

\section{6. 誤差 検討}

以下は各種荷重に対する片持ばりおよび単純ばりのた わみならびにたわみ角を求め, 本法と $M$ 実に追跡した厳密解および在来の塑性解析との比較検討 を取り扱う。

（1）図-12 のごとき片持ばりの自由端 B に集中荷

$$
\text { 図-12 }
$$
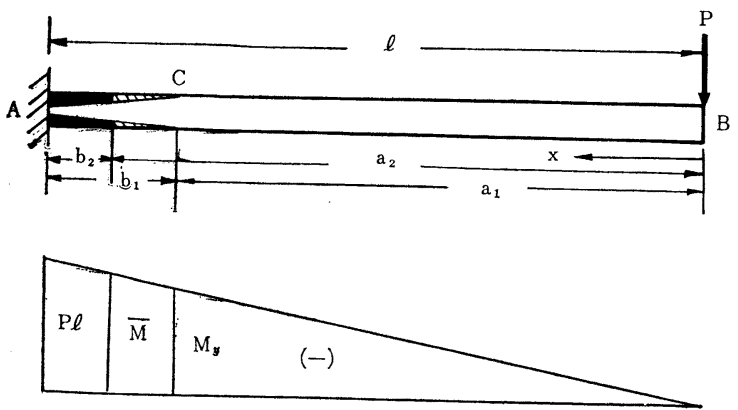

Moment Diagram
重 $P$ が働くとき，同点のたわみおよびたわみ角を算定 すればそれぞれ以下のごとくである。

任意点の曲げモーメントは $M=-P x$ であるゆえ，塑 性領域を $b_{1}, b_{2}$ とすれば $M-\phi$ 第 1 および $M-\phi$ 第 2 近 似直線による $\mathrm{B}$ 点のたわみ $\delta_{1}$ および $\delta_{2}$ は, 式 (9) および式 (10) と式 (14) とよりそれぞれ次式となる。

$$
\begin{aligned}
\delta_{1}= & \int_{0}^{l} \frac{P x^{2}}{E I} d x+\kappa \int_{a_{1}}^{l} \frac{\left(P x+M_{y C}\right) x}{E I} d x \\
= & \frac{P l^{3}}{3 E I}+\frac{\kappa}{E I}\left[\frac{P}{3}\left(l^{3}-a_{1}^{3}\right)+\frac{M_{y C}}{2}\left(l^{2}-a_{1}{ }^{2}\right)\right] \\
\delta_{2}= & \int_{0}^{l} \frac{P x^{2}}{E I} d x+\kappa_{1} \int_{a_{1}}^{l} \frac{\left(P x+M_{y C}\right) x}{E I} d x \\
& +\kappa_{2} \int_{a_{2}}^{l} \frac{\left(P x+\bar{M}_{C}\right) x}{E I} d x \\
= & \frac{P l^{3}}{3 E I}+\frac{\kappa_{1}}{E I}\left[\frac{P}{3}\left(l^{3}-a_{1}{ }^{3}\right)+\frac{M_{y C}}{2}\left(l^{2}-a_{1}{ }^{2}\right)\right] \\
& +\frac{\kappa_{2}}{E I}\left[\frac{P}{3}\left(l^{3}-a_{2}{ }^{3}\right)+\frac{\bar{M}_{C}}{2}\left(l^{2}-a_{2}{ }^{2}\right)\right]
\end{aligned}
$$

ここに, 塑性領域を指定する $a_{1}$ および $a_{2}$ は, 弾塑 性境界の適合条件より $M_{x=a_{1}}=M_{y c}=-M_{y}=-P a_{1}$, $M_{x=a_{2}}=\bar{M}_{C}=-\bar{M}=-P a_{2}$ となるゆえ, $a_{1}=M_{y} / P$, $a_{2}=\bar{M} / P$ となる。また $M_{y}=P_{0} l, \bar{M}=\bar{f} M_{y}$ とおいて 式 (31) に代入して $a_{1}$ および $a_{2}$ を消去すれば, 結局 B点のたわみが荷重比 $\boldsymbol{P}=P / P_{0}$ の関数として求められ 次式となる。

$$
\begin{aligned}
\delta_{1}= & {\left[\frac{\boldsymbol{P}}{3}+\kappa\left\{\frac{\boldsymbol{P}}{3}\left(1-\frac{1}{\boldsymbol{P}^{3}}\right)-\frac{1}{2}\left(1-\frac{1}{\boldsymbol{P}^{2}}\right)\right\}\right] } \\
& \times \frac{M_{y} l^{2}}{E I} \\
\delta_{2}= & {\left[\frac{\boldsymbol{P}}{3}+\kappa_{1}\left\{\frac{\boldsymbol{P}}{3}\left(1-\frac{1}{\boldsymbol{P}^{3}}\right)-\frac{1}{2}\left(1-\frac{1}{\boldsymbol{P}^{2}}\right)\right\}\right.} \\
& \left.+\kappa_{2}\left\{\frac{\boldsymbol{P}}{3}\left(1-\frac{\bar{f}^{3}}{\boldsymbol{P}^{3}}\right)-\frac{1}{2}\left(1-\frac{\bar{f}^{2}}{\boldsymbol{P}^{2}}\right)\right\}\right] \frac{M_{y} l^{2}}{E I}
\end{aligned}
$$

すなわち, 式 (32) の $\delta_{1}$ および $\delta_{2}$ の右辺の第 1 項 $\boldsymbol{P} M_{y} l^{2} / 3 E I$ は, A 端が弾性限界に達する初期降伏荷重 $P_{0}=M_{y} / l$ 以下のときの弾性たわみを示し, 第 2 項以下 を含めたものが A 端に塑性領域を発生した状態より崩 壊に至るまでの弾塑性たわみを与えるものである。

いま断面を長方形と仮定し, 式 (32) に $\kappa=3, \kappa_{1}$ (a) $=0.376, \kappa_{2}=10.50, \bar{f}=1.25$ を代入すれば, たわ み $\delta_{1}$ および $\delta_{2}$ と荷重比 $\boldsymbol{P}$ との関係が 図一13の ごとく求められる。この場合崩壊荷重は

$$
M_{A}=-M_{P}=-1.5 M_{y}=-P l
$$

より,

(b)

$$
P_{P}=1.5 M_{y} / l
$$

とえられるゆえ，崩壊時のたわみ $\delta_{1}{ }^{\circ}$ および $\delta_{2}{ }^{\circ}$ は それぞれ次值となる。

$$
\delta_{1}^{\circ}=0.7222 \frac{M_{y} l^{2}}{E I}
$$


図-13

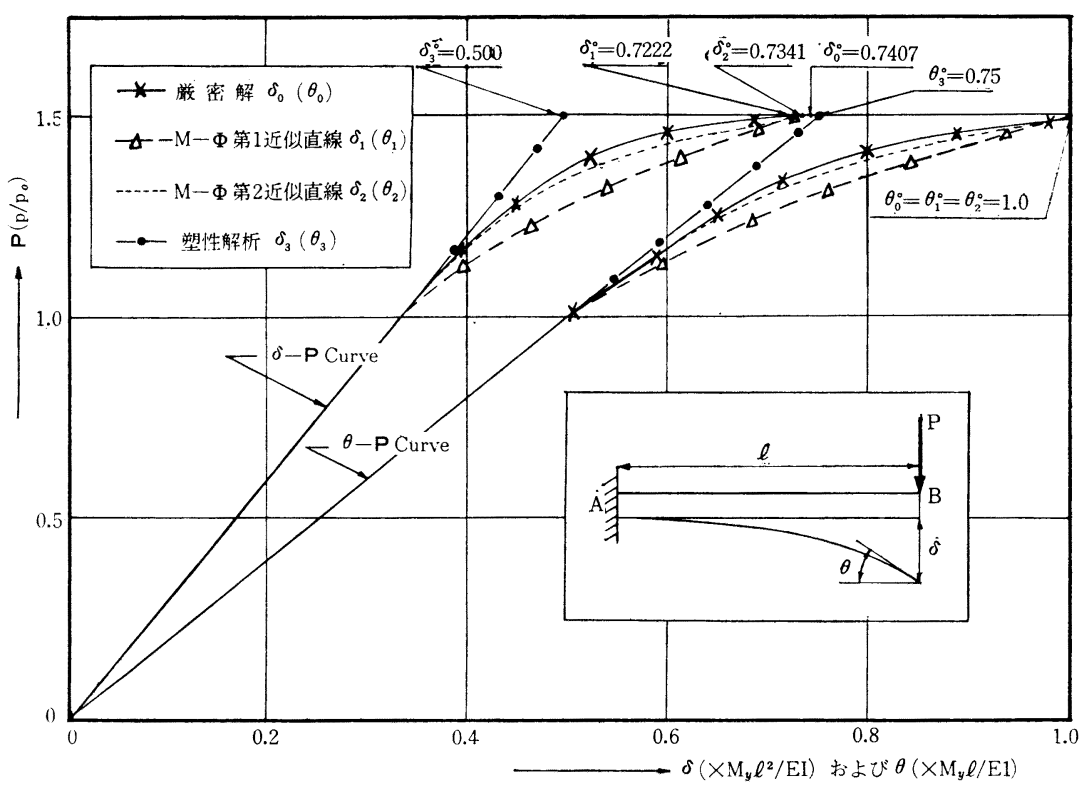

$$
\delta_{2}^{\circ}=0.7341 \frac{M_{y}{ }^{2}}{E I}
$$

同様にたわみ角 $\theta_{1}$ および $\theta_{2}$ は式 $(9)$ ，(10）および 式 (15)より,

$$
\begin{aligned}
\theta_{1\left(M_{B}=0\right)}= & \int_{0}^{l} \frac{P x+M_{B}}{E I} d x+\kappa \int_{a_{1}}^{l} \frac{\left(P x+M_{B}-M_{y}\right)}{E I} d x \\
= & \frac{P l^{2}}{2 E I}+\frac{\kappa}{E I}\left[\frac{P}{2}\left(l^{2}-a_{1}{ }^{2}\right)-M_{y}\left(l-a_{1}\right)\right] \\
\theta_{2\left(M_{B}=0\right)}= & \int_{0}^{l} \frac{P x+M_{B}}{E I} d x+\kappa_{1} \int_{a_{1}}^{l_{1}} \frac{\left(P x+M_{B}-M_{y}\right)}{E I} d x \\
& +\kappa_{2} \int_{a_{2}}^{l} \frac{\left(P x+M_{B}-\bar{M}\right)}{E I} d x \\
= & \frac{P l^{2}}{2 E I}+\frac{\kappa_{1}}{E I}\left[\frac{P}{2}\left(l^{2}-a_{1}{ }^{2}\right)-M_{y}\left(l-a_{1}\right)\right] \\
& +\frac{\kappa_{2}}{E I}\left[\frac{P}{2}\left(l^{2}-a_{2}{ }^{2}\right)-\bar{M}\left(l-a_{2}\right)\right]
\end{aligned}
$$

上式に $a_{1}=l / \boldsymbol{P}, a_{2}=l \bar{f} / \boldsymbol{P}$ を代入して

$$
\begin{aligned}
& \theta_{1}=\left[\frac{\boldsymbol{P}}{2}+\frac{\kappa}{2 \boldsymbol{P}}(\boldsymbol{P}-1)^{2}\right] \frac{M_{y} l}{E I} \\
& \theta_{2}=\left[\frac{\boldsymbol{P}}{2}+\frac{\kappa_{1}}{2 \boldsymbol{P}}(\boldsymbol{P}-1)^{2}+\frac{\kappa_{2}}{2 \boldsymbol{P}}(\boldsymbol{P}-\bar{f})^{2}\right] \frac{M_{y} l}{E I}
\end{aligned}
$$

式（34）のたわみ角と荷重比 $\boldsymbol{P}$ との関係は図一13に 併記するごとくなり, 崩壊時におけるたわみ角 $\theta_{1}^{\circ}$ およ び $\theta_{2}^{\circ}$ はそれぞれ次值となる。

$$
\begin{aligned}
\theta_{1}^{\circ} & =\frac{M_{y} l}{E I} \\
\theta_{2}^{\circ} & =\frac{M_{y} l}{E I}
\end{aligned}
$$

つぎに在来の塑性解析 ${ }^{12)}$ よりたわみ $\delta_{3}{ }^{\circ}$ およびたわみ 角 $\theta_{3}^{\circ}$ を求めると, $\mathrm{A}$ 端が塑性ヒンジになる瞬間まで曲 げモーメントと曲率との関係を弾性と仮定しており, 結 果は次式のごとくである。

$$
\begin{aligned}
& \delta_{3}^{\circ}=\frac{P l^{3}}{3 E I}=0.5 \frac{M_{y} l^{2}}{E I} \\
& \theta_{3}^{\circ}=\frac{P l^{2}}{2 E I}=0.75 \frac{M_{y} l}{E I}
\end{aligned}
$$

さらに $M-\phi$ 曲線を忠実に追跡した厳密解によるたわ み $\delta_{0}$ およびたわみ角 $\theta_{0}$ を求めればつぎのごとくえら れる。すなわち式 (14) に式 (1) および式 (2c) を代入 して,

$$
\delta_{0}=\int_{0}^{a_{1}} \frac{P x^{2}}{E I} d x+\int_{a_{1}}^{l} \frac{M_{y} x d x}{E I \sqrt{3-2 P x / M_{y}}}
$$

上式を積分し, かつ $a_{1}=l / \boldsymbol{P}$ を代入して $a_{1}$ を消去す れば,

$$
\delta_{0}=\frac{M_{y} l^{2}}{3 E I}\left[\frac{5}{\boldsymbol{P}^{2}}-\left(\frac{1}{\boldsymbol{P}}+\frac{3}{\boldsymbol{P}^{3}}\right) \sqrt{3-2 \boldsymbol{P}}\right]
$$

特に崩壊時のたわみ $\delta_{0}{ }^{\circ}$ は式 (35) に $\boldsymbol{P}_{P}=1.5$ を代 入して次值となる。

$$
\delta_{0}^{\circ}=0.7407 \frac{M_{y} l^{2}}{E I}
$$

たわみ角 $\theta_{0}$ も同様に式 (15) に式 (1) および式 (2c) を代入して計算すれば,

$$
\theta_{0}=\frac{M_{y} l}{\boldsymbol{P} E I}\left[\frac{3}{2}-\sqrt{3-2 \boldsymbol{P}}\right]
$$

したがって崩壊時のたわみ角は同じく $\boldsymbol{P}_{P}=1.5$ を代 入して, $\theta_{0}^{\circ}=M_{y} l / E I$ となる。

以上より本法を厳密解と比較すれば, 崩壊時における たわみの誤差は $\delta_{1}{ }^{\circ}$ で $2.5 \%, \delta_{2}^{\circ}$ で $0.94 \%$, また, たわ み角は全く一致しており,これに対して塑性解析による たわみ $\delta_{3}{ }^{\circ}$ およびたわみ角 $\theta_{3}{ }^{\circ}$ の誤差はそれぞれ $32.5 \%$ および $25 \%$ の過小評価となっていることがわかる。

さらに本例の片持ばりに等分布荷重が作用した場合の 
B 点のたわみを同一手法で算定すれば，崩壊時における たわみは本法と厳密解とは一致し，

$$
\grave{\delta}_{1}^{\circ}=\delta_{2}^{\circ}=\delta_{0}^{\circ}=M_{y} l^{2} / 2 E I
$$

となる。

（2）図一10 の単純ばりの中央載荷点のたわみを 6.

（1）の場合と同様に本法で解けば次式の結果となる。

$$
\begin{aligned}
& \hat{\delta}_{1}=\frac{P l^{3}}{48 E I}+\frac{\kappa}{6 E I}\left[P\left(\frac{l^{3}}{8}-a_{1}{ }^{3}\right)-3 M_{y}\left(\frac{l^{2}}{4}-a_{1}{ }^{2}\right)\right] \\
& =\frac{M_{y} l^{2}}{12 E I}\left[\boldsymbol{P}+\frac{\kappa}{\boldsymbol{P}^{2}}\left\{\left(\boldsymbol{P}^{3}-1\right)-\frac{3}{2}\left(\boldsymbol{P}^{2}-1\right)\right\}\right] . \\
& \delta_{2}=\frac{P l^{3}}{48 E I}+\frac{\kappa_{1}}{6 E I}\left[P\left(\frac{l^{3}}{8}-a_{1}{ }^{3}\right)-3 M_{y}\left(\frac{l^{2}}{4}-a_{1}{ }^{2}\right)\right] \\
& +\frac{\kappa_{2}}{6 E I}\left[P\left(\frac{l^{3}}{8}-a_{2}{ }^{3}\right)-3 \bar{M}\left(\frac{l^{2}}{4}-a_{2}{ }^{2}\right)\right] \\
& =\frac{M_{y} l^{2}}{12 E I}\left[\boldsymbol{P}+\frac{\kappa_{1}}{\boldsymbol{P}^{2}}\left\{\left(\boldsymbol{P}^{3}-1\right)-\frac{3}{2}\left(\boldsymbol{P}^{2}-1\right)\right\}\right. \\
& \left.+\frac{\boldsymbol{\kappa}_{2}}{\boldsymbol{P}^{\boldsymbol{\varepsilon}}}\left\{\left(\boldsymbol{P}^{3}-\bar{f}^{3}\right)-\frac{3}{2}\left(\boldsymbol{P}^{2}-\bar{f}^{2}\right)\right\}\right]
\end{aligned}
$$

ただし，

$\boldsymbol{P}=P / P_{0}, \quad P_{0}=4 M_{y} / l, \quad a_{1} / l=1 / 2 \boldsymbol{P}, a_{2} / l=\bar{f} / 2 \boldsymbol{P}$ 式 (36) および式 (37) を図示すれば図一11 のごとき 結果となる。特に崩壊荷重 $P_{P}$ は

より

$$
M_{C}=P l / 4=M_{P}=1.5 M_{y}
$$

$$
P_{P}=6 M_{y} / l
$$

となり, したがって, $\boldsymbol{P}_{P}=1.5$ となる。これを式 (36)

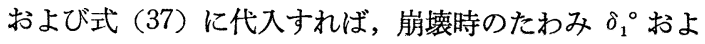
び $\hat{o}_{2}^{\circ}$ がただちに求められ次值となる。

$$
\begin{aligned}
& \grave{o}_{1}{ }^{\circ}=0.1806 \frac{M_{y} l^{2}}{E I} \\
& \delta_{2}{ }^{\circ}=0.1836 \frac{M_{y} l^{2}}{E I}
\end{aligned}
$$

また峳密解によるたわみ $\delta_{0}$ は式 (29) の $\delta_{M+Q}$ より $\delta_{Q}$ だけ差し引いた值に等しいゆえ， $\boldsymbol{P}_{P}=1.5$ を代入す れば崩壊時のたわみ $\delta_{0}^{\circ}$ として次值をうる。

$$
\delta_{0}{ }^{\circ}=0.1852 \frac{M_{y} l^{2}}{E I}
$$

したがって, 本法における崩壊時のたわみの誤差は $\delta_{1}{ }^{\circ}$ で $2.5 \%, \delta_{2}{ }^{\circ}$ で $0.86 \%$ となり, 一方の塑性解析に よるたわみ $\delta_{3}{ }^{\circ}=0.125 M_{y} l^{2} / E I$ が $32.5 \%$ の誤差を有 するのに比較してきわめて高精度であることが確認され る。

以上の二例を顧みて本法で用いた近似が在来の塑性解 析にくらべはるかにすぐれ, しかも演算面において厳密 解とは比較にならぬほどの簡易さを有することが了解さ れる。

\section{7. 弾塑性たわみ角式の誘導}

弾塑性領域を考慮したたわみ角式を $M-\phi$ 第 2 近似值 線に基づく補正エネルギー式より以下に誘導し，塑性領
域および塑性ヒンジの各種発生状態をあらかじめ想定し て，使用に便なるごとく個々に提示せんとするむのであ る。なお誘導諸式において $\kappa_{1}=\kappa, \kappa_{1}=0$ とおけば当然 $M-\phi$ 第 1 近似直線に基づく実用たわみ角式がえられる。

\section{（1）両端に塑性領域が生ずる場合}

図一14 に示すごとく $\mathrm{A}, \mathrm{B}$ 両端よりそれぞれ $A \bar{C}$, $B \bar{D}$ および $\bar{C} C, \bar{D} D$ の範囲に 3. で定義した第 2 およ び第 1 塑性領域をもつ弾塑性部材 $\mathrm{AB}$ を考えれば, 部 材全体に貯えられる補正エネルギー式は式 (10) より次 式となる。

$$
\begin{aligned}
& U=\int_{0}^{l} \frac{M^{2}}{2 E I} d x+\kappa_{1} \int_{0}^{a_{1}} \frac{\left(M-M_{y a}\right)^{2}}{2 E I} \\
& +\kappa_{2} \int_{0}^{a_{2}} \frac{\left(M-\bar{M}_{a}\right)^{2}}{2 E I} d x+\kappa_{1} \int_{l-b_{1}}^{l} \frac{\left(M-M_{y b}\right)^{2}}{2 E I} d x \\
& \quad+\kappa_{2} \int_{l-b_{2}}^{l} \frac{\left(M-\bar{M}_{b}\right)^{2}}{2 E I} d x \ldots \ldots \ldots \ldots \ldots \ldots \ldots . .(38)
\end{aligned}
$$

ここに, $M_{y a}, M_{y b}$ はそれぞれ $\mathrm{C}, \mathrm{D}$ 点の降伏曲げ モーメント $M_{y}$ を表わし， $\bar{M}_{a}, \bar{M}_{b}$ はそれぞれ $\bar{C}, \bar{D}$ 点の臨界曲げモーメント $\bar{M}$ を表わす。

\section{図-14}

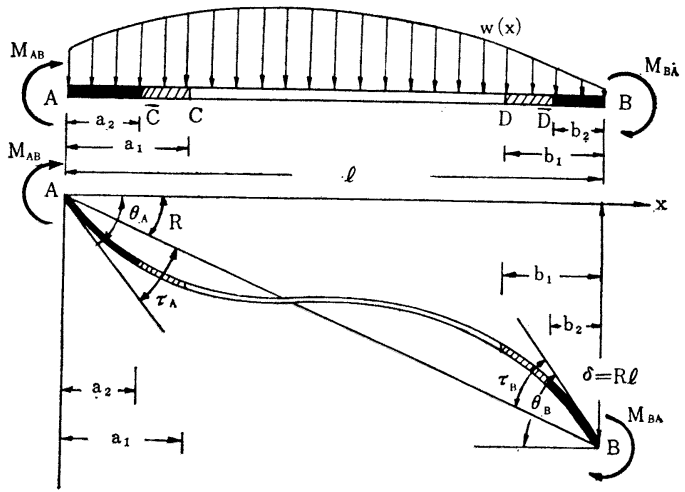

図一14 より任意点の曲げモーメントはつぎのごとく 表わされる。

$$
M=\frac{l-x}{l} M_{A B}-\frac{x}{l} M_{B A}+M_{0}
$$

ただし， $M_{0}$ は $\mathrm{AB}$ 材を単純ばりと見做したときの荷 重による任意点の曲げモーメントを示す。

式 (38) に式 (39) を代入して式 (15) を適用すれば, 両端 $\mathrm{A}, \mathrm{B}$ における切線角 $\tau_{A}, \tau_{B}$ がそれぞれ次式で与 えられる。

$$
\begin{aligned}
\left(\frac{E I}{l}\right) \tau_{A}= & M_{A B}\left[\frac{1}{3}+\sum_{i=1}^{2} \kappa_{i} \frac{l^{3}-\left(l-a_{i}\right)^{3}+b_{i}{ }^{3}}{3 l_{3}}\right] \\
& +M_{B A}\left[-\frac{1}{6}+\sum_{i=1}^{2} \kappa_{i}\right. \\
& \left.\times \frac{2\left(a_{i}{ }^{3}+b_{i}{ }^{3}\right)-3 l\left(a_{i}{ }^{2}+b_{i}{ }^{2}\right)}{6 l^{3}}\right] \\
& -M_{y a} \frac{2 l a_{1}-a_{1}{ }^{2}}{2 l^{2}} \kappa_{1}-M_{y b} \frac{b_{6}{ }^{2}}{2 l^{2}} \kappa_{1}
\end{aligned}
$$




$$
-\bar{M}_{a} \frac{2 l a_{2}-a_{2}{ }^{2}}{2 l^{2}} \kappa_{2}-\bar{M}_{b} \frac{b_{2}{ }^{2}}{2 l^{2}} \kappa_{2}+C_{1}
$$

$$
\begin{aligned}
\left(\frac{E I}{l}\right) \tau_{B}= & M_{A B}\left[-\frac{1}{6}+\sum_{i=1}^{2} \kappa_{i}\right. \\
& \left.\times \frac{2\left(a_{i}{ }^{3}+b_{i}{ }^{3}\right)-3 l\left(a_{i}{ }^{2}+b_{i}{ }^{2}\right)}{6 l^{3}}\right] \\
& +M_{B A}\left[\frac{1}{3}+\sum_{i=1}^{2} \kappa_{i} \frac{l^{3}-\left(l-b_{i}\right)^{3}+a_{i}{ }^{3}}{3 l^{3}}\right] \\
& +M_{y a} \frac{a_{1}{ }^{2}}{2 l^{2}} \kappa_{1}+M_{y b} \frac{2 l b_{1}-b_{1}{ }^{2}}{2 l^{2}} \kappa_{1} \\
& +\bar{M}_{a} \frac{a_{2}{ }^{2}}{2 l^{2}} \kappa_{2}+\bar{M}_{b} \frac{2 l b_{2}-b_{2}{ }^{2}}{2 l^{2}} \kappa_{2}-C_{2}
\end{aligned}
$$

ここに, $C_{1}$ および $C_{2}$ は外的荷重によって決まり， つぎのごとき内容をもつ。

$$
\begin{aligned}
\boldsymbol{C}_{1}= & \int_{0}^{l} M_{0} \frac{l-x}{l^{2}} d x+\sum_{i=1}^{2} \kappa_{i} \int_{0}^{a_{i}} M_{0} \frac{l-x}{l^{2}} d x \\
& +\sum_{i=1}^{2} \kappa_{i} \int_{l-b_{i}}^{l} M_{0} \frac{l-x}{l^{2}} d x \\
\boldsymbol{C}_{2}= & \int_{0}^{l} M_{0} \frac{x}{l^{2}} d x+\sum_{i=1}^{2} \kappa_{i} \int_{0}^{a_{i}} M_{0} \frac{x}{l^{2}} d x \\
& +\sum_{i=1}^{2} \kappa_{i} \int_{l-b_{i}}^{l} M_{0} \frac{x}{l^{2}} d x
\end{aligned}
$$

さて, 式 (40), (41) に $\tau_{A}=\theta_{A}-R, \tau_{B}=\theta_{B}-R$ お よび $\phi_{A}=2 E K_{0} \theta_{A}, \quad \phi_{B}=2 E K_{0} \theta_{B}, \quad \psi_{A B}=-6 E K_{0} R$ の慣用置換を行なったのち, 連立に解いて $M_{A B}, M_{B A}$
を求めれば, 結局所要の弾塑性たわみ角式がえられ下記 の式 (42a) となる。

$$
\begin{aligned}
M_{A B}= & k_{A B}\left(\alpha_{A B} \phi_{A}+\beta_{A B} \phi_{B}+\gamma_{A B} \psi_{A B}\right) \\
& +\xi_{a} M_{y a}+\xi_{b} M_{y b}+C_{A B} \\
M_{B A}= & k_{A B}\left(\alpha_{B A} \phi_{B}+\beta_{B A} \phi_{A}+\gamma_{B A} \psi_{A B}\right) \\
& +\eta_{a} M_{y a}+\eta_{b} M_{y b}+C_{B A}
\end{aligned}
$$

ただし， $k=K / K_{0}$ は剛比， $\alpha, \beta, \gamma$ および $\xi, \eta$ は形 状項で表一3 において $c_{i=1,2}=d_{i=1,2}=0$ としたものに合 致する。ここで設計に多用される薄肉断面に高精度を示 す $M-\phi$ 第 1 近似直線の場合 $\left(\kappa_{1}=\kappa, \kappa_{2}=0\right)$ について, 上記形状項を数表化して実用に供しめるごとくした。紙

\begin{tabular}{|c|c|c|c|}
\hline \multicolumn{4}{|r|}{ 表一3 } \\
\hline$\alpha_{A B}$ & $\frac{\nu_{1}}{2 \nu}$ & $\xi_{a}$ & $\frac{k_{1}}{\nu}\left(\frac{a_{1}}{l} \nu_{1}-\frac{a_{1}^{2}}{2 l^{2}} \nu_{2}\right)+\frac{\kappa_{2} \bar{f}}{\nu}\left(\frac{a_{2}}{l} \nu_{1}-\frac{a_{2}^{2}}{2 l^{2}} \nu_{2}\right)$ \\
\hline$\beta_{A B}$ & $\frac{\nu_{2}-\nu_{1}}{2 \nu}$ & $\xi_{b}$ & $\frac{\kappa_{1}}{\nu}\left\{\frac{b_{1}}{l} \nu_{1}-\frac{l^{2}-\left(l-b_{1}\right)^{2}}{2 l^{2}} \nu_{2}\right\}+\frac{k_{2} \bar{f}}{\nu}\left\{\frac{b_{2}}{l} \nu_{1}-\frac{l^{2}-\left(l-b_{2}\right)^{2}}{2 l^{2}} \nu_{2}\right\}$ \\
\hline$r A B$ & $\frac{\nu_{2}}{6 \nu}$ & $\xi_{c}$ & $\frac{c_{1}}{\nu}\left\{\frac{c_{1}}{l^{2}}\left(\nu_{1} l-\nu_{2} l_{1}\right)+\frac{c_{1}^{2}}{2 l^{2}} \nu_{2}\right\}+\frac{\kappa_{2} \widetilde{f}}{\nu}\left\{\frac{c_{2}}{l^{2}}\left(\nu_{1} l-\nu_{2} l_{1}\right)+\frac{c_{2}^{2}}{2 l^{2}} \nu_{2}\right\}$ \\
\hline$\alpha_{B A}$ & $\frac{\nu_{1}-\nu_{2}+\nu_{3}}{2 \nu}$ & $\xi_{d}$ & $\frac{\kappa_{1}}{\nu}\left\{\frac{d_{1}}{l^{2}}\left(\nu_{1} l-\nu_{2} l_{1}\right)-\frac{d_{1}^{2}}{2 l^{2}} \nu_{2}\right\}+\frac{\kappa_{2} \widetilde{f}}{\nu}\left\{\frac{d_{2}}{l^{2}}\left(\nu_{1} l-\nu_{2} l_{1}\right)-\frac{d_{2}^{2}}{2 l^{2}} \nu_{2}\right\}$ \\
\hline$\beta_{B A}$ & $\frac{\nu_{2}-\nu_{1}}{2 \nu}$ & $\eta_{a}$ & $\frac{\kappa_{1}}{\nu}\left\{\frac{a_{1}}{l^{2}}\left(\nu_{2}-\nu_{1}\right)-\frac{a_{1}^{2}}{l^{2}} \nu_{3}\right\}+\frac{\kappa_{2} \bar{f}}{\nu}\left\{\frac{a_{2}}{l}\left(\nu_{2}-\nu_{1}\right)-\frac{\alpha_{2}^{2}}{2 l^{2}} \nu_{2}\right\}$ \\
\hline$\gamma_{B A}$ & $\frac{\nu_{3}}{6 \nu}$ & $\eta_{b}$ & $\frac{\kappa_{1}}{\nu}\left\{\frac{b_{1}}{l}\left(\nu_{2}-\nu_{1}\right)-\frac{l^{2}-\left(l-b_{1}\right)^{2}}{2 l^{2}} \nu_{3}\right\}+\frac{\kappa_{2} \bar{f}}{\nu}\left\{\frac{b_{2}}{l}\left(\nu_{2}-\nu_{1}\right)-\frac{l^{2}-\left(l-b_{2}\right)^{2}}{2 l^{2}} \nu_{3}\right\}$ \\
\hline$C_{A B}$ & $\frac{1}{\nu}\left\{C_{2}\left(\nu_{2}-\nu_{1}\right)-C_{1} \nu_{1}\right\}$ & $\eta_{c}$ & $\frac{\kappa_{1}}{\nu}\left\{\frac{c_{1}}{l^{2}}\left(\nu_{2} l-\nu_{1} l-\nu_{3} l_{1}\right)+\frac{c_{1}^{2}}{2 l^{2}} \nu_{3}\right\}+\frac{\kappa_{2} \overline{\bar{\gamma}}}{\nu}\left\{\frac{c_{2}}{l^{2}}\left(\nu_{2} l-\nu_{1} l-\nu_{3} l_{1}\right)+\frac{c_{2}{ }^{2}}{2 l^{2}} \nu_{3}\right\}$ \\
\hline$C_{B A}$ & $\frac{1}{\nu}\left\{\boldsymbol{C}_{1}\left(\nu_{1}-\nu_{2}+\nu_{3}\right)-\boldsymbol{C}_{2}\left(\nu_{2}-\nu_{1}\right)\right\}$ & $\eta_{d}$ & $\frac{\kappa_{1}}{\nu}\left\{\frac{d_{1}}{l^{2}}\left(\nu_{2} l-\nu_{1} l-\nu_{3} l_{1}\right)-\frac{d_{1}^{2}}{2 l^{2}} \nu_{3}\right\}+\frac{\kappa_{2} \bar{f}}{\nu}\left\{\frac{d_{2}}{l^{2}}\left(\nu_{2} l-\nu_{1} l-\nu_{3} l_{1}\right)-\frac{d_{2}{ }^{2}}{2 l^{2}} \nu_{3}\right\}$ \\
\hline$\nu$ & $\nu_{1}\left(\nu_{2}+\nu_{3}\right)-\nu_{2}^{2}$ & $\nu_{1}$ & $\frac{1}{3}+\sum_{i=1}^{2} \frac{\kappa_{i}}{3 l^{3}}\left\{l^{3}-\left(l-b_{i}\right)^{3}+a_{i}^{3}+3\left(c_{i}+d_{i}\right) l_{1}^{2}-3\left(c_{i}^{2}-d_{i}^{2}\right) l_{1}+\left(c_{i}^{3}+d_{i}^{3}\right)\right\}$ \\
\hline \multirow[t]{2}{*}{ [注] } & \multirow{2}{*}{$\begin{array}{l}M-\phi \text { 第 } 1 \text { 近似直線の場合は } \\
\kappa_{1}=\kappa, \quad \kappa_{2}=0 \text { とおく。 }\end{array}$} & $\nu_{2}$ & $\frac{1}{2}+\sum_{i=1}^{2} \frac{\kappa_{i}}{2 l^{2}}\left\{l^{2}-\left(l-b_{i}\right)^{2}+a_{i}^{2}+2\left(c_{i}+d_{i}\right) l_{1}-\left(c_{i}^{2}-d_{i}{ }^{2}\right)\right\}$ \\
\hline & & $\nu_{3}$ & $\frac{1}{2}+\sum_{i=1}^{2} \frac{\kappa_{i}}{2 l^{2}}\left\{l^{2}-\left(l-a_{i}\right)^{2}+b_{i}^{2}+2\left(c_{i}+d_{i}\right) l_{2}+\left(c_{i}{ }^{2}-d_{i}{ }^{2}\right)\right\}$ \\
\hline
\end{tabular}
面の都合上本研究では計算結果のごく一部を長方形断面 $(\kappa=3)$ を例にとり，無次元化した塑性領域 $a_{1} / l, b_{1} / l$ を それぞれ横軸とパラメーターにして, 図表一1 5 にか かげた。一般に塑性領域の増加とともに, 図表一1 の $\alpha$ 值は减少し部材の曲渆性の低下が判読され, さらに図 表-4, 5 の $|\xi|,|\eta|$ はともに増大し, 固定端モーメント が降伏応力に起因する降伏曲げモーメントにいちじるし く影響されることが確認された。なお各図表において併 記したカッコ内の形状項に対しては, 横軸とパラメータ 一とをそれぞれ同じくカッコした $b_{1} / l, a_{1} / l$ を用いて読 みとればよい。

また荷重項 $C_{A B}, C_{B A}$ の基礎をなす $\boldsymbol{C}_{1}$ および $\boldsymbol{C}_{2}$ に ついて, 主たる荷重状態 3 種に対する一般算式を算出す 
れば，結果は表-4 の各式において $c_{i=1,2}=d_{i=1,2}=0$ と したものに一致するゆえ，同表に包含することにする。

a) 一端に塑性ヒンジが生ずる場合＼cjkstart図一15(a)に 示すごとく $\mathrm{B}$ 端に塑性ヒンジが形成された場合は, 式 (42 a) で $M_{B A}=M_{P B}$ (B 点の塑性曲げモーメント) とおいて次式をうる。

$$
\begin{aligned}
M_{A B}= & k_{A B}\left(\alpha_{A B}{ }^{\prime} \phi_{A}+r_{A B} \psi_{A B}\right)+\xi_{a}{ }^{\prime} M_{y a} \\
& +\xi_{b} M_{y b}+\beta_{A B} M_{P B}+H_{A B} \cdots \cdots(42 \mathrm{~b})
\end{aligned}
$$

図表-1

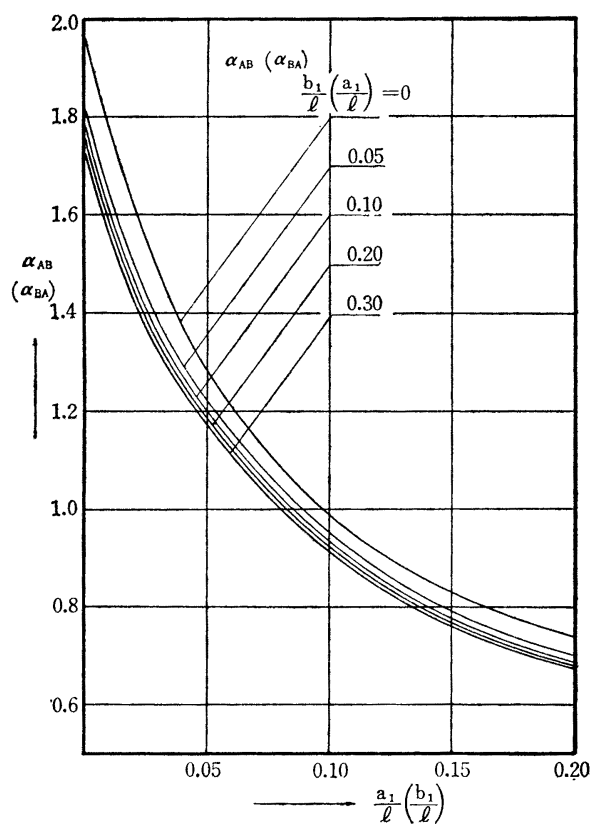

図表-2

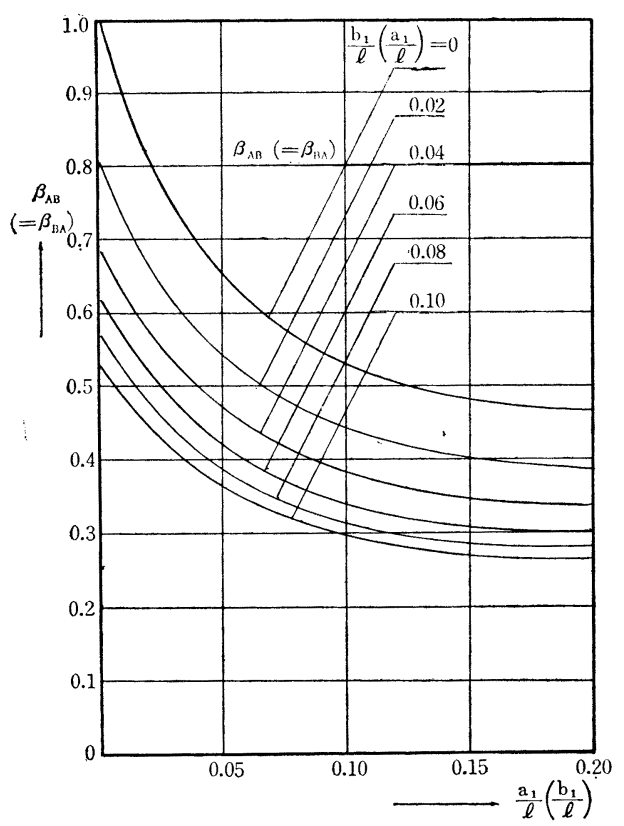

ここに,

$\alpha_{A B^{\prime}}=\frac{1}{2\left(\nu_{1}-\nu_{2}+\nu_{3}\right)}$

$\beta_{A B^{\prime}}=\frac{\nu_{2}-\nu_{1}}{\nu_{1}-\nu_{2}+\nu_{3}}$

$r_{A B^{\prime}}=\frac{1}{6\left(\nu_{1}-\nu_{2}+\nu_{3}\right)}$

$\xi_{a}^{\prime}=\frac{1}{\nu_{1}-\nu_{2}+\nu_{3}}\left\{\kappa_{1}\left(\frac{a_{1}}{l}-\frac{a_{1}{ }^{2}}{2 l^{2}}\right)+\kappa_{2} \bar{f}\left(\frac{a_{2}}{l}-\frac{a_{2}{ }^{2}}{2 l^{2}}\right)\right\}$

図表-3

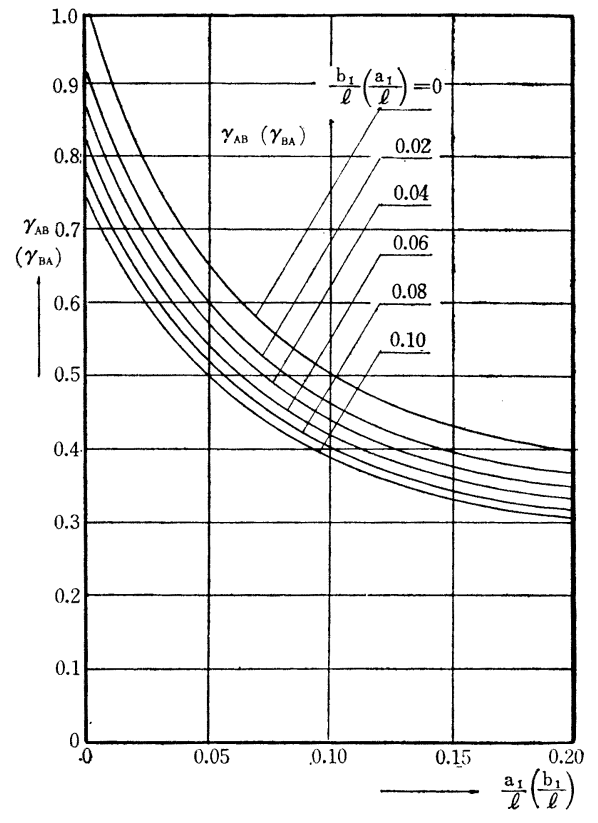

図表-4

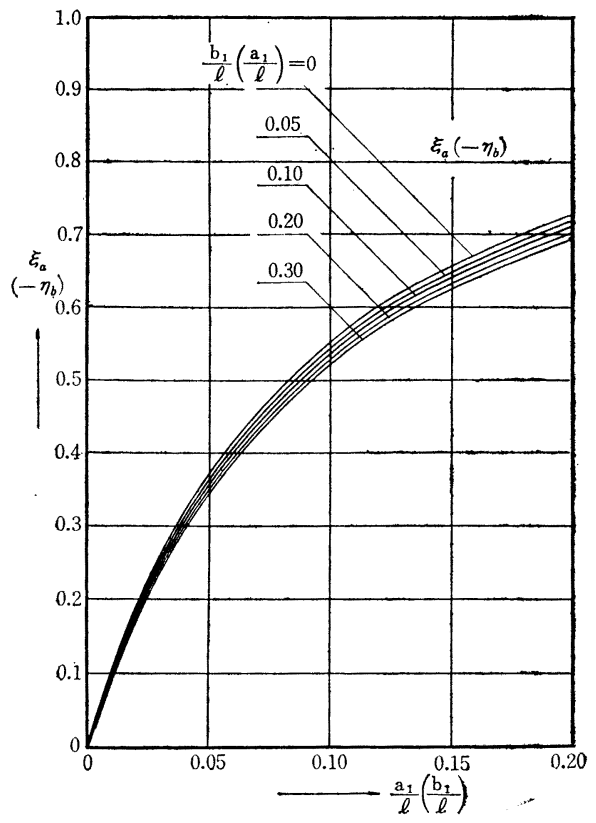


表-4

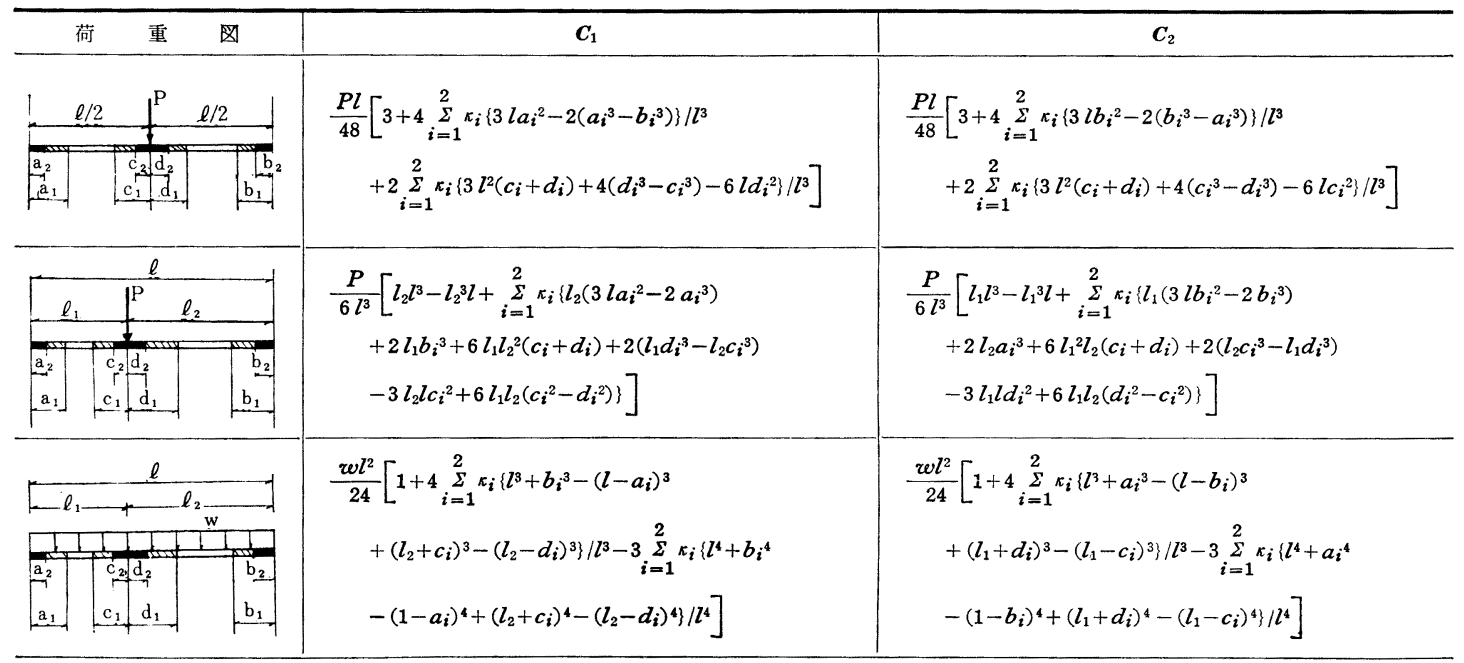

図表一5

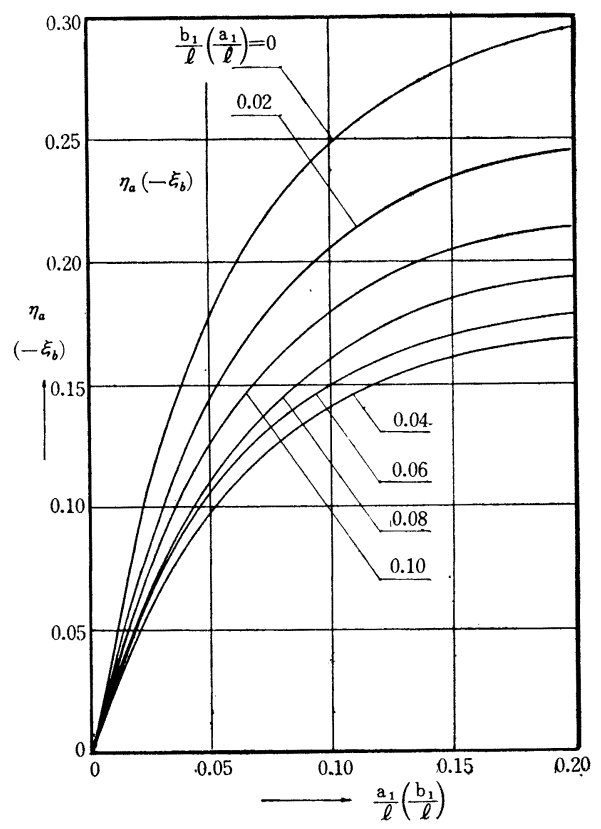

図-15
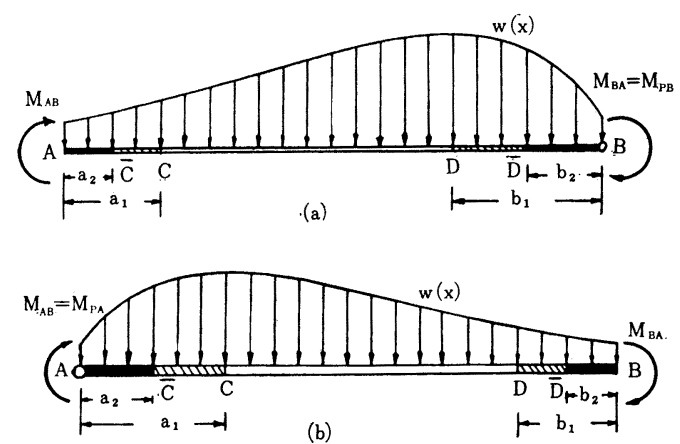

$$
\begin{aligned}
\xi_{b}{ }^{\prime}= & \frac{1}{\nu_{1}-\nu_{2}+\nu_{3}}\left\{\kappa_{1}\left(\frac{b_{1}}{l}+\frac{b_{1}{ }^{2}-2 l b_{1}}{2 l^{2}}\right)\right. \\
& \left.+\kappa_{2} \bar{f}\left(\frac{b_{2}}{l}+\frac{b_{2}{ }^{2}-2 l b_{2}}{2 l^{2}}\right)\right\} \\
H_{A B}= & -\frac{C_{1}}{\nu_{1}-\nu_{2}+\nu_{3}}
\end{aligned}
$$

なお $\nu_{1}, \nu_{2}, \nu_{3}$ は表一3において $c_{i=1,2}=d_{i=1,2}=0$ と したものに合致し, また $\boldsymbol{C}_{1}$ は式 (40) のそれと同じく, 次記する $\boldsymbol{C}_{2}$ も式 (41) の内容と同様である。

つぎに図一15 (b) のごとく A 端に塑性ヒンジが形成 された場合が考えられるが，いまと全く同様に $M_{A B}=$ $M_{P A}$ とおいて

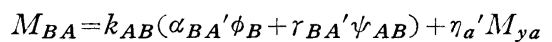

$$
\begin{aligned}
& +\eta_{b}{ }^{\prime} M_{y b}+\beta_{B A^{\prime}} M_{y}+H_{B A}
\end{aligned}
$$

ここに, $M_{P A}$ は $\mathrm{A}$ 点の塑性曲げモーメントを表わ ᄂ,

$$
\begin{aligned}
& \alpha_{B A^{\prime}}=\frac{1}{2 \nu_{1}}, \quad \beta_{B A^{\prime}}=\frac{\nu_{2}-\nu_{1}}{\nu_{1}} \\
& \gamma_{B A^{\prime}}=\frac{1}{6 \nu_{1}}, \quad H_{B A}=\frac{C_{2}}{\nu_{1}} \\
& \eta_{a^{\prime}}=-\frac{1}{\nu_{1}}\left\{\kappa_{1} \frac{a_{1}{ }^{2}}{2 l^{2}}+\kappa_{2} \bar{f} \frac{a_{2}{ }^{2}}{2 l^{2}}\right\} \\
& \eta_{b}{ }^{\prime}=-\frac{1}{\nu_{1}}\left\{\kappa_{1} \frac{b_{1}{ }^{2}-2 l b_{1}}{2 l^{2}}+\kappa_{2} \bar{f} \frac{b_{2}{ }^{2}-2 l b_{2}}{2 l^{2}}\right\}
\end{aligned}
$$

$\nu_{1}, \nu_{2}$ は式 (42 b) の場合と一致する。

b) 塑性領域が生じない場合 B 端に塑性領域が生 じない場合は, 式 (42 a) で $b_{1}=b_{2}=0$ とおけばよく, ま た, A, B 両端に塑性領域が生じない場合は, 式 (42 a) で $a_{i=1,2}=b_{i=1,2}=0$ とおけばつぎの弾性慣用式がえられ るのは当然であり, ここでの $C_{A B}, C_{B A}$ はもちろん弾 性時の荷重項の内容に帰せられている。

$$
\left.\begin{array}{l}
M_{A B}=k_{A B}\left(2 \phi_{A}+\phi_{B}+\psi_{A B}\right)+C_{A B} \\
M_{B A}=k_{A B}\left(2 \phi_{B}+\phi_{A}+\psi_{A B}\right)+C_{B A}
\end{array}\right\}
$$




\section{（2）両端および途中に塑性領域が生ずる場合}

構造形式および荷重状態によっては, 図一16 に示す ごとく塑性領域が部材の両端および途中に生ずる場合が ある。この場合も 7.（1）と同様に両端および途中の塑 性領域をも入れて誘導すれば次式の結果をうる。

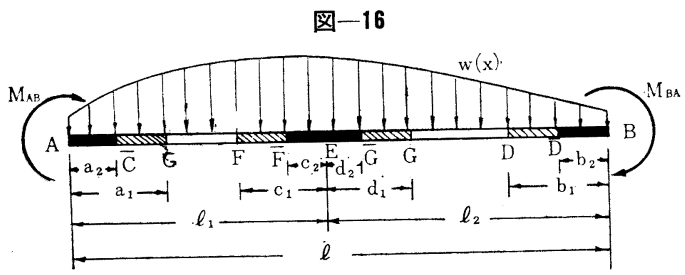

$$
\left.\begin{array}{rl}
M_{A B}= & k_{A B}\left(\alpha_{A B} \phi_{A}+\beta_{A B} \phi_{B}+\gamma_{A B} \psi_{A B}\right) \\
& +\xi_{a} M_{y a}+\xi_{b} M_{y b}+\xi_{c} M_{y c}+\xi_{d} M_{y d}+C_{A B} \\
M_{B A}= & k_{A B}\left(\alpha_{B A} \phi_{B}+\beta_{B A} \phi_{A}+\gamma_{B A} \psi_{A B}\right) \\
& +\eta_{a} M_{y a}+\eta_{b} M_{y b}+\eta_{c} M_{y c}+\eta_{d} M_{y d}+C_{B A}
\end{array}\right\}
$$

ここに, 形状項 $a, \beta, r, \xi, \eta$ および荷重項 $C_{A B}$, $C_{B A}$ は 表一3 に示すごとき内容をもつ。すなわち表一3 の係数は $c_{i=1,2}=d_{i=1,2}=0$ とした式 $(42 \mathrm{a})$ および $a_{i=1,2}=b_{i=1,2}=0$ とした途中にのみ塑性領域が生ずる場 合をもその特例として包含している。また $C_{A B}, C_{B A}$ の基礎をなす $\boldsymbol{C}_{1}$ および $\boldsymbol{C}_{2}$ はつぎのごとく示される。

$$
\begin{aligned}
\boldsymbol{C}_{1}= & \int_{0}^{l} M_{0} \frac{l-x}{l^{2}} d x+\sum_{i=1}^{2} \kappa_{i} \int_{0}^{a_{i}} M_{0} \frac{l-x}{l^{2}} d x \\
& +\sum_{i=1}^{2} \kappa_{i} \int_{l-b_{i}}^{l} M_{0} \frac{l-x}{l^{2}} d x \\
& +\sum_{i=1}^{2} \kappa_{i} \int_{l_{1}-c_{i}}^{l_{1}} M_{0} \frac{l-x}{l^{2}} d x \\
& +\sum_{i=1}^{2} \kappa_{i} \int_{l_{1}}^{l_{1}+d_{i}} M_{0} \frac{l-x}{l^{2}} d x \\
\boldsymbol{C}_{2}= & \int_{0}^{l} M_{0} \frac{x}{l^{2}} d x+\sum_{i=1}^{2} \kappa_{i} \int_{0}^{a_{i}} M_{0} \frac{x}{l^{2}} d x \\
& +\sum_{i=1}^{2} \kappa_{i} \int_{l-b_{i}}^{l} M_{0} \frac{x}{l^{2}} d x \\
& +\sum_{i=1}^{2} \kappa_{i} \int_{l_{1}-c_{i}}^{l_{1}} M_{0} \frac{x}{l_{2}} d x \\
& +\sum_{i=1}^{2} \kappa_{i} \int_{l_{1}}^{l_{1}+d_{i}} M_{0} \frac{x}{l^{2}} d x
\end{aligned}
$$

主たる荷重状態 3 種に対する $\boldsymbol{C}_{1}, \boldsymbol{C}_{2}$ の值を式 (44) よ り算定すれば 表一4 をうる。すなわち 表-4 の各式は 7. (1) における $\boldsymbol{C}_{1}, \boldsymbol{C}_{2}$ の值および途中にのみ塑性領域 が生ずる $a_{i=1,2}=b_{i=1,2}=0$ とした場合のそれらをもその

図-17

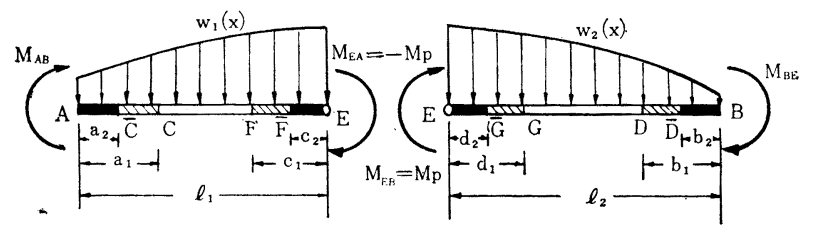

特例としてすべて包含しており，塑性領域 $a_{i}, b_{i}, c_{i}, d_{i}$ $(i=1,2)$ などの発生状況に応じてその都度適宜取捨選 択し，それぞれに対応するたわみ角式である式 (42) お よび式 (43) とともに使用するものである。

（3）途中に塑性ヒンジが生ずる場合

部材の途中に塑性ヒンジが形成された場合は, 図一17 のごとく塑性ヒンジ点 $\mathrm{E}$ で部材を 2 分し $\mathrm{AE}$ と $\mathrm{EB}$ の 両材に分け，それぞれに式 (42b) および式 (42 c) を適 用してこれを解決する手法をとる。

\section{8. 不静定構造物の弾塑性解析法}

本たわみ角式を用うることにより，多層多スパンの長 方形ラーメンや連続ばりなど各種不静定構造物の弾塑性 解析が可能となるが，その解法骨子は慣用の弾性たわみ 角法と類似であり，弾塑性境界条件式としての曲げモー メントの適合条件式が加わるのみといえる。

すなわち構造物の各節点における節点方程式および必 要に応じて層方程式たるせん断力のつりあい式を用いて 未知たわみ角および未知部材角と同数の方程式をうると ともに, さらに塑性領域範囲を示す $a_{i}, b_{i}, c_{i}, d_{i}(i=1$, 2) などの未知数に対してはつぎの弾塑性境界条件が成 立する。たとえば図一14 における第 1 および第 2 塑性 領域の先端 $\mathrm{C}$ および $\overline{\mathrm{C}}$ 点の算出曲げモーメントが，そ れぞれ降伏曲げモーメント $M_{y a}$ および臨界曲げモーメ ント $\bar{M}_{a}$ に等しかるべき条件を用いて式 (39) より次 式をうる。

$$
\left.\begin{array}{l}
M_{x=a_{1}}=M_{y a}=\frac{l-a_{1}}{l} M_{A B}-\frac{a_{1}}{l} M_{B A}+M_{0}\left(a_{1}\right) \\
M_{y=a_{2}}=\bar{M}_{a}=\frac{l-a_{2}}{l} M_{B A}-\frac{a_{2}}{l} M_{B A}+M_{0}\left(a_{2}\right)
\end{array}\right\}
$$

ここに， $M_{y a}$ および $\bar{M}_{a}$ の符号はそれぞれ C 点お よび $\overline{\mathrm{C}}$ 点の算出曲げモーメントの符号と一致する。

また, $b_{i}, c_{i}, d_{i}(i=1,2)$ に対しても式 (45) と同様 な条件式が対応するゆえ, 結局塑性領域の未知数と同数 の方程式がえられることになる。

なお，図一17 のごとく材の途中に塑性ヒンジが形成 される場合には, 部材を 2 つないし 3 つに分ける関係 上, その分岐点を節点と見做して取り报うゆえ, 未知た わみ角と末知部材角とが結局増えることになり, 前述の 塑性領域範囲が未知数であることを考慮すれば，一般に 弾性たわみ角法よりも未知数の数がかなり多くなり,さ らに上記方程式の性質からいって 1 回の連立解法 で処置できず，くり返し試算を要する点などが原 因となって, 計算手法は多少繁雑となる。しかし 電子計算機の利用によりこれらの難点も克服しう る今日においては, かなり複雑な構造物も取り扱 うことが可能となったが, 本論文では簡単な例を 
用いて 9. に計算手法の詳細を紹介することとし，その 大要のみを述べれば以下のごとくである。

（1）与えられた荷重により曲げモーメントを算出す る場合

（i）与荷重により構造物の弾性解析を行ない, 曲げ モーメント図を算定し, 弾性限すなわち降伏曲げモーメ ント $M_{y}$ を越えている断面があれば, その塑性領域を 式 (45) などより上記算出弾性曲げモーメント值をまず 使用して第 1 次近似值を決定する。

(ii) この塑性領域を式 (42a) 式 (43) のうち必要 な式を選んで代入し, 節点方程式たる曲げモーメントの つりあい式および層方程式たるせん断力のつりあい式を 連立に解いて弾塑性曲げモーメント図を算定する。

(iii）（ii）で算出した弾塑性曲げモーメント值を（i） で使用した式 (45) などに代入して塑性領域を改めて算 出し, 再び (ii) の算定を行ない, 曲げモーメントが収 㪘に至るまでこれをくり返す。したがって与荷重に対す る弾塑性たわみも, ただちに $\delta=R \cdot l$ としてえられる。

\section{（2）与えられた塑性領域により荷重值を算出する場} 合

式 (42 a) 式 (43) より与えられた塑性領域に対応す るたわみ角式をえらび, 各形状項 $\alpha, \beta, \gamma, \xi, \eta$ および 荷重項 $C_{A B}, C_{B A}$ などをそれぞれ 表一3 および 表一4 より算定する。節点方程式および層方程式と式 (45) な どの弾塑性境界条件式とを連立に解けば所要の荷重值が えられる。

この解法は一端に塑性領域が生ずる場合か, 両端にお いて対称あるいは途中において対称に塑性領域が生ずる 場合にのみ適用可能で, しからざる場合は本質的にかか る問題が起こらない。

\section{（3）崩壊荷重時まで追跡する場合}

（i） まず荷重を $P$ で一般表示のらえ弾性解析を行 ない，曲げモーメント図を算出する。

(ii）つぎに $M_{\max }$ の断面で上下縁の応力がちょう ど弾性限界に達した状態（図一2（b）参照）を考え，こ れに対応する初期降伏荷重 $P_{0}$ および初期降伏の起こる 位置を弾性的に算定する。

（iii） 荷重が $P_{0}$ より大きい $P_{1}$ に増加した状態に移 行する。当然塑性領域が発生し, これを式 (45) などよ り算出するが, 右辺の端モーメントが末知数ゆえ, まず 第1次近似值として（3）（i）で弾性的に算出した端モ ーメント值に含まれる $P$ に $P_{1}$ を使用する。

(iv) 8. (1)の (ii), (iii) の操作をくり返すことに より，塑性領域ならびに曲げモーメントを収㪘させる。

（v）つぎに荷重を逐次漸増させ $\left(P_{2}, P_{3}, \cdots\right)$, 上記 (iii) (iv) の操作をくり返して逐次発生して行く塑性 領域および塑性ヒンジを追跡しながら崩壊荷重 $P_{P}$ まで 算定すればよい。

\section{9. 計 算 例}

計算手法を紹介する目的で, 以下に実用解法としての $M-\phi$ 第 1 近似直線を用いて静定および不静定ばりにつ いての弾塑性解析を行なう。

(1) 図一18 のごとき長方形断面ゲルバーばりに集 中荷重 $P=6 \mathrm{t}$ および等分布荷重 $w=0.8 \mathrm{t} / \mathrm{m}$ が作用す るとき, 塑性領域ならびに $\mathrm{B}$ 点のたわみを算定すればつ ぎのごとくである。ただし鋼材として SS 41 (降伏点応 力 $\sigma_{y}=3200 \mathrm{~kg} / \mathrm{cm}^{2}$, 断面 $6.0 \times 10.0 \mathrm{~cm}$ ) を使用する ものとする。

\section{図-18}
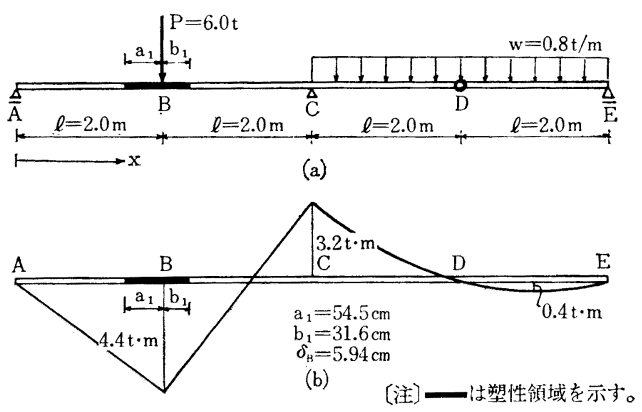

任意点の曲げモーメントは

$\mathrm{A} \sim \mathrm{B}$ 間 $(0 \leqq x \leqq l)$ で

$$
M=\frac{P-w l}{2} x
$$

$\mathrm{B} \sim \mathrm{C}$ 間 $(l \leqq x \leqq 2 l)$ で

$$
M=P\left(l-\frac{x}{2}\right)-\frac{w l}{2} x .
$$

$\mathrm{C} \sim \mathrm{E}$ 間 $(2 l \leqq x \leqq 4 l)$ で

$$
M=-\frac{w}{2}\left(x^{2}-7 l x+12 l^{2}\right)
$$

したがって曲げモーメント図は 図一-18 (b) のごとく なり, 降伏曲げモーメント值が $M_{y}=b h^{2} \sigma_{y} / 6=3.2 \mathrm{t} \cdot \mathrm{m}$ であるゆえ，これを上回る B 点近傍に塑性領域が発生し ていることがわかる。いま B 点より A方向およびC 方向 の塑性領域をそれぞれ $a_{1}$ および $b_{1}$ とすれば，式 (46a) および式 (46 b) より弾塑性境界の適合条件はそれぞれ 次式となる。

$$
\begin{aligned}
& M_{y}=\frac{P-w l}{2}\left(l-a_{1}\right) \\
& M_{y}=P\left(l-\frac{l+b_{1}}{2}\right)-\frac{w l}{2}\left(l+b_{1}\right)
\end{aligned}
$$

上式に $M_{y}=3.2 \mathrm{t} \cdot \mathrm{m}, P=6 t, w=0.8 \mathrm{t} / \mathrm{m}, l=2 \mathrm{~m}$ を 代入して $a_{1}$ および $b_{1}$ を求めれば次值をうる。

$$
a_{1}=0.545 \mathrm{~m}, b_{1}=0.316 \mathrm{~m} \cdots \cdots \cdots \cdots \cdots \cdots \cdots \cdots \cdot(47)
$$

さらにB点のたわみ $\delta_{B}$ は式 (9) と式 (14) よりつ ぎのごとくえられる。

$$
\delta_{B}=\int_{0}^{l} \frac{(P-w l)}{4 E I} x^{2} d x
$$




$$
\begin{aligned}
& +\frac{1}{E I} \int_{l}^{2 l}\left\{P\left(l-\frac{x}{2}\right)^{2}-\frac{w l}{2}\left(l x-\frac{x^{2}}{2}\right)\right\} d x \\
& +\frac{\kappa}{E I} \int_{l-a_{1}}^{l}\left\{\frac{(P-w l)}{4} x^{2}-\frac{M_{y}}{2} x\right\} d x \\
& +\frac{\kappa}{E I} \int_{l}^{l+a_{2}}\left\{P\left(l-\frac{x}{2}\right)^{2}-\frac{w l}{2}\left(l x-\frac{x^{2}}{2}\right)\right. \\
& \left.-M_{y}\left(l-\frac{x}{2}\right)\right\} d x \\
& =\frac{(2 P-3 w l) l^{3}}{12 E I}+\frac{\kappa}{E I}\left[-\frac{P-w l}{2}\left\{l^{3}-\left(l-a_{1}\right)^{3}\right\}\right. \\
& -\frac{M_{y}}{4}\left\{l^{2}-\left(l-a_{1}\right)^{2}\right\} \\
& +P\left\{l^{2} b_{1}-\frac{l\left(l+b_{1}\right)^{2}-l^{3}}{2}-\frac{\left(l+b_{1}\right)^{3}-l^{3}}{12}\right\} \\
& -\frac{w l}{2}\left\{\frac{l\left(l+b_{1}\right)^{2}-l^{3}}{2}-\frac{\left(l+b_{1}\right)^{3}-l^{3}}{6}\right\} \\
& \left.-M_{y}\left\{l b_{1}-\frac{\left(l+b_{1}\right)^{2}-l^{2}}{4}\right\}\right]
\end{aligned}
$$

ここで上式の第 1 項は弾性たわみを表わし $\delta=4.57$ $\mathrm{cm}$ となり, 第 2 項以下を含めた弾塑性たわみは式 (47) および諸值を代入して $\delta=5.94 \mathrm{~cm}$ をうる。

なお, 等分布荷重 $w=0.8 \mathrm{t} / \mathrm{m}$ で一定值に止め, 集中 荷重 $P$ を漸増させたとき, その崩壊過程は 図一19 に示 すごとくなる。

（2）図一20 のごとき連続ばりが等分布荷重 $w=$ $4 M_{y} / l^{2}$ と集中荷重 $P$ とを受けて, 中央に $0.1 l$ だけ塑 性領域を生じた状態における集中荷重 $P$ とそのときの 曲げモーメント図を求める。

はり $\mathrm{AB}$ 材に式 $(42 \mathrm{~d})$ を, $\mathrm{BC}$ 材に $a_{i=1,2}=b_{i=1,2}=$
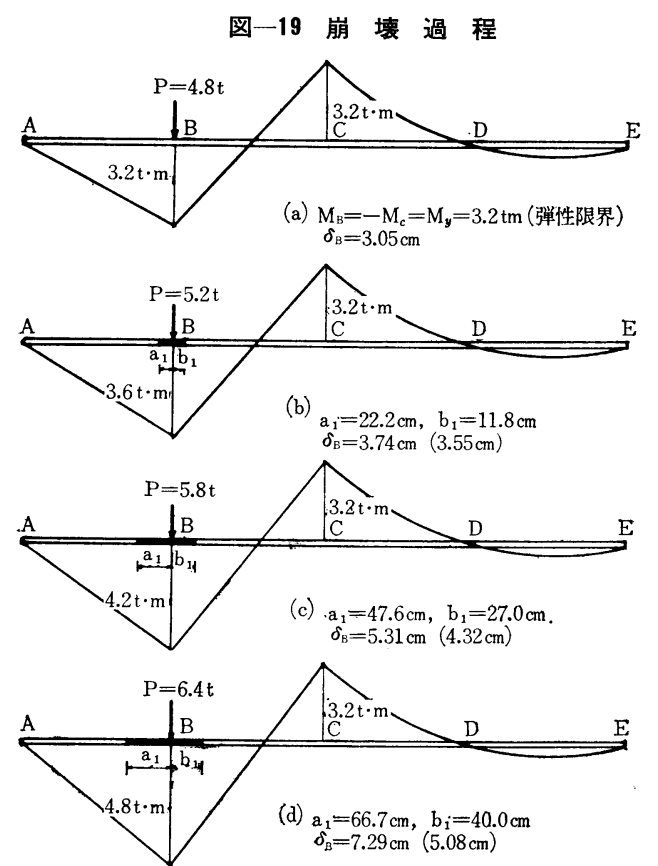

〔注〕一は塑性領域を, 括弧内の数字は 弾性材としての値を示す。
図-20
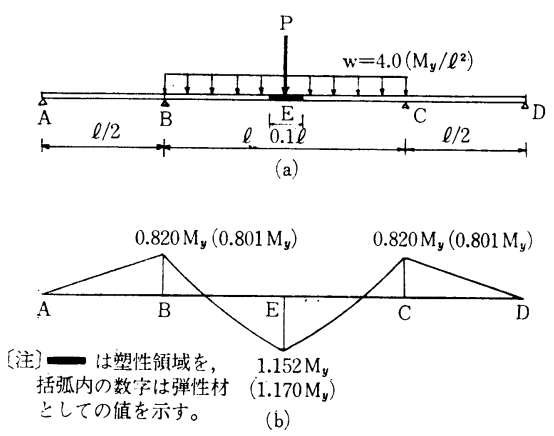

$c_{2}=d_{2}=0$ として式 (43) を適用し, 剛比をそれぞれ $k_{A B}=2, k_{B C}=1$ とすれば, 対称性より左半分に着目し て次式をうる。

$$
\begin{aligned}
& M_{A B}=2 \times 1.5 \phi_{B}=3 \phi_{B} \\
& M_{B C}=\left(\alpha_{B C}-\beta_{B C}\right) \phi_{B}+\xi_{c} M_{y c}+\xi_{d} M_{y d}+C_{B C}
\end{aligned}
$$

ここで諸係数を $c_{1}=d_{1}=0.05 l, \quad l_{1}=l_{2}=l / 2$ として

表一3 より算出すれば, 次值をうる。

$\alpha_{B C}=1.88, \beta_{B C}=1.11, \xi_{c}=0.138, \xi_{d}=0.093$

また荷重項 $C_{B C}$ は, まず表一4 より $C_{1}\left(=C_{2}\right)$ を算 出すれば,

$$
C_{1}=0.0604 w l^{2}+0.0981 P l
$$

よって $w=4 M_{y} / l^{2}$ と $\nu_{2}=0.65$ を代入して

$$
C_{B C}=-C_{1} / \nu_{2}=-0.371 M_{y}-0.151 P l
$$

さらに $M_{y c}=M_{y d}=+M_{y}$ を用うれば，上記 $M_{B C}$ は 結局つぎの内容となる。

$$
M_{B C}=0.769 \phi_{B}-0.141 M_{y}-0.151 P l \cdots(49)
$$

$\mathrm{B}$ 点の節点方程式 $M_{B A}+M_{B C}=0$ に式 (48) c式 (49) とを代入して次式をうる。

$$
3.77 \phi_{B}-0.151 P l=0.141 M_{y}
$$

一方弾塑性境界条件より

$$
\begin{aligned}
M_{y c}= & M_{y}=\frac{1}{2}\left(P l+w l^{2}\right)\left(0.5-\frac{c_{1}}{l}\right) \\
& +M_{B C}-\frac{w l^{2}}{2}\left(1-\frac{c_{1}}{l}\right)^{2}
\end{aligned}
$$

上式に式 (49) および $w=4 M_{y} / l^{2}, c_{1}=0.05 l$ を代入 すれば，

$0.769 \phi_{B}+0.074 P l=0.646 M_{y}$.

式 (50) と式 (51) とを連立に解いて

$$
\phi_{B}=0.273 M_{y}, \quad P=5.89 M_{y}
$$

よって式 (48) と式 (49)より

$$
M_{B A}=0.820 M_{y}, \quad M_{B C}=-0.820 M_{y}
$$

また $\mathrm{E}$ 点の曲げモーメントは

$$
M_{E}=\frac{w l^{2}}{8}+\frac{P l}{4}+M_{B C}=1.15 M_{y}
$$

以上より所要の曲げモーメント図は 図一20 (b) のご とくなる。

（3）図一21 のごとき長方形断面の両端固定ばりが, 
図一21荷重一たわ み曲線

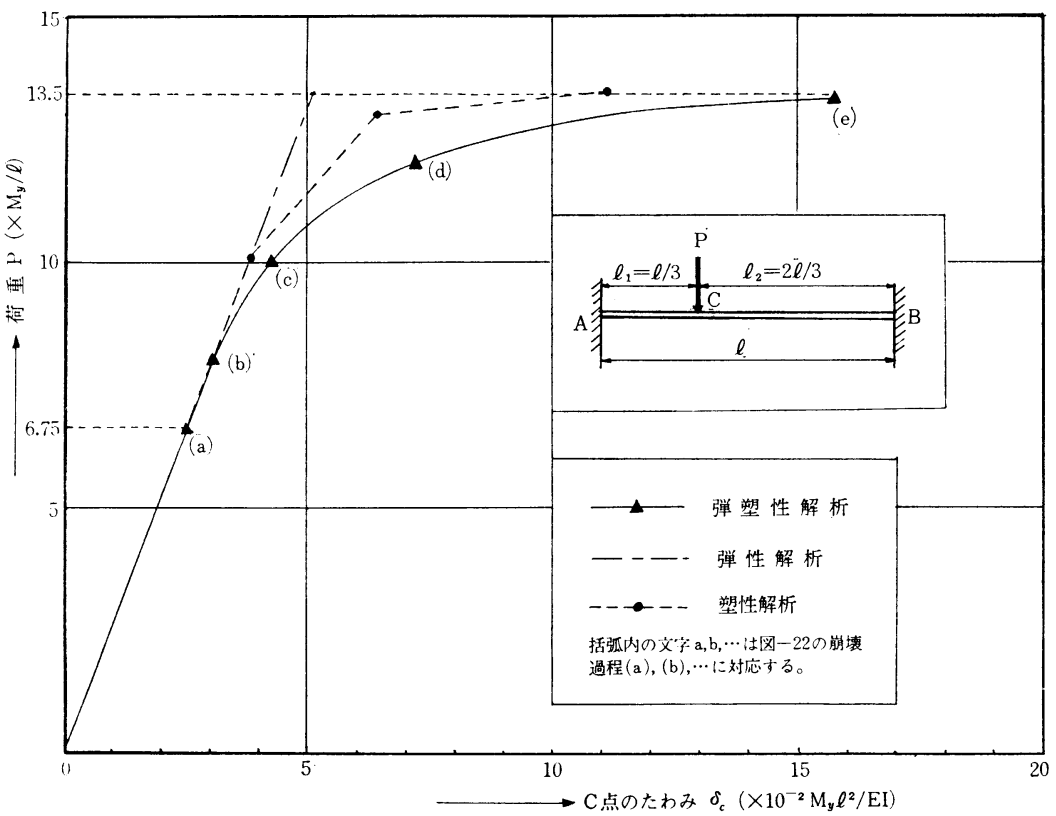

集中荷重 $P$ を受けて崩壊するまでの荷重 $P$ と $\mathrm{C}$ 点の たわみ $\delta_{C}$ との関係を求めればつぎのとおりである。

（i ） 初期降伏荷重の算定

まず弾性的に解くと次值をうる。

$$
\begin{aligned}
& M_{A C}=-4 P l / 27 \\
& M_{C A}=-8 P l / 81 \\
& M_{B C}=2 P l / 27
\end{aligned}
$$

A端の曲げモーメントの絶対值が最大であるから，A 端の断面が最初に $M_{y}$ に達する。よって初期降伏荷重 $P_{0}$ は $M_{A C}=-M_{y}$ とおくことにより $P_{0}=6.75 M_{y} / l$ が 求まり, 曲げモーメント図は図一22 (a) のごとくえられ る。

（ii） $\mathrm{A}$ 端に引き続き $\mathrm{C}$ 点に塑性領域が生ずる場合

荷重を $P_{0}$ より大きい $P_{1}$ にすれば $\mathrm{A}$ 端に引き続き $\mathrm{C}$ 点にも塑性領域が生ずるゆえ，式 (43) を

$$
a_{2}=b_{1}=b_{2}=c_{2}=d_{2}=0
$$

としてそのまま適用すればよいが，ここでは C 点に塑性 ヒンジが形成されることをあらかじめ想定し，はり AB を $\mathrm{AC}$ と $\mathrm{CB}$ に分けて考え, それぞれの剛比を $k_{A C}=2$ および $k_{C B}=1$ として各部材に式 (42a) を適用すれば, 端モーメントはつぎのごとく表わされる。

$$
\begin{aligned}
& M_{A C}=2\left(\beta_{A C} \phi_{C}+r_{A C} \psi_{A C}\right)+\xi_{a} M_{y a}+\xi_{c} M_{y c} \\
& M_{C A}=2\left(\alpha_{C A} \phi_{C}+r_{C A} \psi_{A C}\right)+\eta_{a} M_{y a}+\eta_{c} M_{y c} \\
& M_{C B}=1\left(\alpha_{C B} \phi_{C}+r_{C B} \psi_{C B}\right)+\xi_{d} M_{y d} \\
& M_{B C}=1\left(\beta_{B C} \phi_{C}+r_{B C} \psi_{C B}\right)+\eta_{d} M_{y d}
\end{aligned}
$$

しかるに $\psi_{C B}=-0.5 \psi_{A C}$ で未知数は $\phi_{C}$ と $\psi_{A C}$ と

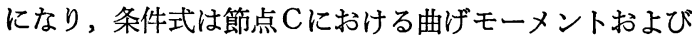

せん断力のつりあい式として次式が成立する。

$$
\left.\begin{array}{l}
M_{C A}+M_{C B}=0 \\
M_{A C}+M_{C A}-0.5\left(M_{C B}+M_{B C}\right)=-P l / 3
\end{array}\right\}
$$
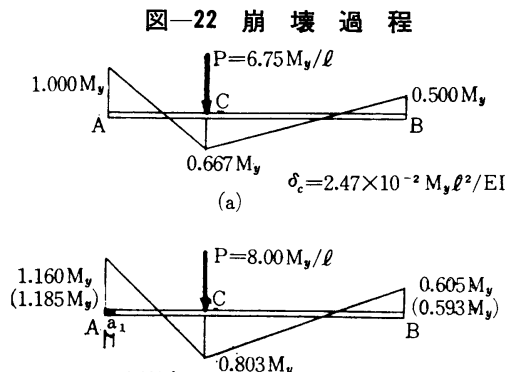

$a_{1}=0.081 \ell_{1} \quad\left(-0.790 \mathrm{M}_{y}\right) \delta_{c}=3.02 \times 10^{-2} \mathrm{M}_{y} \ell^{2} / \mathrm{EI}$ (b) $\quad\left(2.93 \times 10^{-2} \mathrm{M}_{\mathbf{y}} \ell^{2} / \mathrm{EI}\right)$
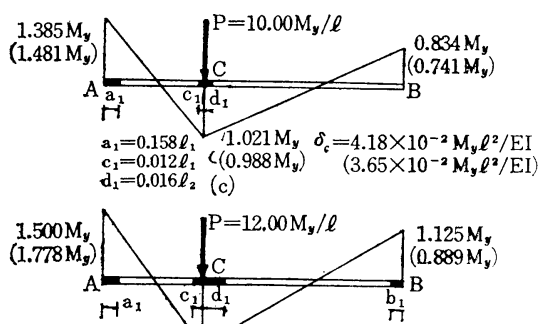

$\mathrm{a}_{1}=0.181 \ell_{1} \quad 1.267 \mathrm{M}_{\mathrm{y}} \quad \delta_{c}=7.23 \times 10^{-2} \mathrm{M} \ell^{2} / \mathrm{EI}$

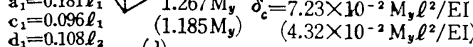
$d_{1}=0.108 \ell_{2} \quad(d)$

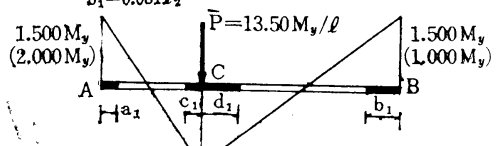

$\mathrm{a}_{1}=0.167 \ell_{1} / 1.500 \mathrm{M}_{\mathrm{y}} \delta_{c}=16.1 \times 10^{-2} \mathrm{M}_{y} \ell^{2} / \mathrm{EI}$

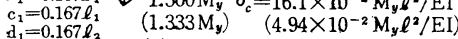
$\mathrm{b}_{1}=0.167 \ell_{2} \quad$ (e)

〔注〕山塑性領域を, 括弧内の数字は弾性材 としての値を示す。 
表一 5

\begin{tabular}{c|c|c}
\hline$\varphi_{c}$ & $\psi_{A C}$ & 右 \\
\hline $2 \alpha_{C A}+\alpha_{C B}$ & $2 r_{C A}+r_{C B}$ & $\left(\eta_{a}-\eta_{c}-\xi_{d}\right) M_{y}$ \\
\hline $2\left(\beta_{A C}+\alpha_{C A}\right)-0.5\left(\alpha_{C B}+\beta_{C B}\right)$ & $2\left(\gamma_{A C}+r_{C A}\right)+0.25\left(r_{C B}+r_{B C}\right)$ & $\left(\xi_{a}-\xi_{c}+\eta_{a}-\eta_{c}+0.5 \xi_{d}+0.5 \eta_{d}\right) M_{y}-P l / 3$ \\
\hline
\end{tabular}

表一6

\begin{tabular}{|c|c|c|}
\hline$\varphi_{c}$ & $\psi_{A D}$ & 辺 \\
\hline $2 \alpha_{C A^{\prime}+\alpha_{C B}}$ & $2 r_{C A^{\prime}}-0.5 r_{C B}$ & $\left(\eta_{a}^{\prime}-\eta_{c^{\prime}}-\xi_{d}+\xi_{b}+1.5 \beta_{A C^{\prime}}\right) M_{y}$ \\
\hline $2 \alpha_{C A^{\prime}-0.5\left(\alpha_{C B}+\beta_{B C}\right)}$ & $2 \gamma_{C A^{\prime}}+0.25\left(\gamma_{C B}+r_{B C}\right)$ & $\left\{\eta_{a^{\prime}}-\eta_{c^{\prime}}+1.5 \beta_{A C^{\prime}}+0.5\left(\xi_{d}-\xi_{b}+\eta_{d}-\eta_{b}\right)+1.5\right\} M_{y}-P l / 3$ \\
\hline
\end{tabular}

式 (54) に式 (53) を代入すれば 表一5 のごとき連立 方程式がえられ，また塑性領域 $a_{1}, c_{1}, d_{1}$ は式 (45) な どより次式となる。

$$
\begin{aligned}
& a_{1}=\frac{M_{A C}+M_{y}}{M_{A C}+M_{C A}} l_{1}, \quad\left|M_{A C}\right|>M_{y} \\
& c_{1}=\frac{M_{C A}+M_{y}}{M_{A C}+M_{C A}} l_{1}, \quad\left|M_{C A}\right|>M_{y} \\
& d_{1}=\frac{M_{C B}-M_{y}}{M_{C B}+M_{B C}} l_{2}, \quad\left|M_{C B}\right|>M_{y}
\end{aligned}
$$

なお，C点のたわみ $\delta_{C}$ は表一-5 の連立方程式を解け ばつぎのごとく求められる。

$$
\delta_{C}=R_{A C} l_{1}=-\frac{\psi_{A C} l^{2}}{27 E I}
$$

以上の諸式と 表一5 より所要の解をうるが, その手法 をいま $P=8.0 M_{y} / l$ の場合について行なえばつぎのご とくなる。

式 (52) に $P=8.0 M_{y} / l$ を代入して, 曲げモーメン トの第 1 次近似值がつぎのごとくえられる。

$$
\begin{aligned}
& M_{A C}=-1.185 M_{y} \\
& M_{C A}=-0.791 M_{y} \\
& M_{B C}=0.593 M_{y}
\end{aligned}
$$

したがって A 端のみに塑性領域が生じていることが わかり, 式 (55) より $a_{1}=0.094 l_{1}, c_{1}=d_{1}=0$ がえら れ，これを用いて各形状項を算出すればつぎのごとくな るが，図表一1〜 5 より読み取っても 1 桁ぐらいの精度 の低下を認めれば，十分利用できることが了解されるで あろう。

すなわち,

$$
\begin{array}{lll}
\alpha_{C A}=1.789, & \beta_{A C}=0.543, & \gamma_{A C}=0.519, \\
\gamma_{C A}=0.777, & \xi_{a}=0.529, & \eta_{a}=0.244, \\
\alpha_{C B}=2.0, & \gamma_{C B}=1.0, & \xi_{d}=0, \\
\beta_{B C}=1.0, & \gamma_{B C}=1.0, & \eta_{d}=0
\end{array}
$$

これらを表一 5 に代入して連立に解けばつぎの值をう る。

$$
\phi_{C}=0.198, \quad \psi_{A C}=-0.815
$$

よって式 (53) より曲げモーメントの第 2 次近似值が 下記のごとくえられる。

$$
\begin{aligned}
& M_{A C}=-1.160 M_{y} \\
& M_{C A}=-0.803 M_{y}
\end{aligned}
$$

$$
M_{B C}=0.605 M_{y}
$$

これを再び式 (55) に代入して $a_{1}=0.082 l_{1}$ を算出 し，以下これをくり返すことにより，最終的に 図一22 (b) に示す曲げモーメント図をうる。

$P=10.0 M_{y} / l$ の場合についても, 同じ手法で計算す れば曲げモーメント図は 図一22(c) に示すごとき収㪘 值となる。

(iii） A 端に塑性ヒンジが形成される場合

さらに荷重が増加すると， A 端の曲げモーメントが $M_{P}$ に達し, $\mathrm{A}$ 端に塑性ヒンジが形成される。

すなわち $\mathrm{AC}$ 材には式 $(42 \mathrm{c})$ を $M_{P A}=-1.5 M_{y}$ とおき， $C B$ 材には式 (42a) を適用すれば次式をうる。

$$
\begin{aligned}
& M_{A C}=-1.5 M_{y} \\
& M_{C A}=2\left(\alpha_{C A^{\prime}} \phi_{C}+\gamma_{C A^{\prime}} \psi_{A C}\right) \\
& +\left(\eta_{c}{ }^{\prime}-\eta_{a}{ }^{\prime}-1.5 \beta_{A C^{\prime}}\right) . M_{y} \\
& M_{C B}=1\left(\alpha_{C B} \phi_{C}+\gamma_{C B} \psi_{C B}\right)+\left(\xi_{d}-\xi_{b}\right) M_{y} \\
& M_{B C}=1\left(\beta_{B C} \phi_{C}+\gamma_{B C} \psi_{C B}\right)+\left(\eta_{d}-\eta_{b}\right) M_{y}
\end{aligned}
$$

これらを式 (54) に代入すれば，表一6 がえられる。 また塑性領域 $b_{1}$ は弾塑性境界条件より次式となる。

$$
b_{1}=\frac{M_{B C}+M_{y}}{M_{C B}+M_{B C}} l_{2}, \quad\left|M_{B C}\right|>M_{y}
$$

以上の諸式ならびに表一6 を用いて $P=12.0 M_{y} / l$ の 場合を算出すれば 図一22(d) の結果となる。

(iv) $\mathrm{A}$ 端についで $\mathrm{C}$ 点にも塑性ヒンジが形成され る場合

$\mathrm{AC}$ 材の両端モーメントをいずれも塑性モーメントと し， CB 材に式 (42 c) を適用すれば次式となる。

$$
\left.\begin{array}{l}
M_{A C}=-M_{P}=-1.5 M_{y} \\
M_{C A}=-M_{P}=-1.5 M_{y} \\
M_{C B}=+M_{P}=1.5 M_{y} \\
M_{B C}=\gamma_{B C} \psi_{C B}+\left(\eta_{d}^{\prime}-\eta_{b}{ }^{\prime}+1.5 \beta_{C B}^{\prime}\right) M_{y}
\end{array}\right\}
$$

よって上式を式（54）の第 2 式に代入すれば次式をう る。

$$
\begin{aligned}
\psi_{A C}= & \frac{1}{0.25 \gamma_{B C^{\prime}}}\left[-\frac{P l}{3}\right. \\
& \left.+\left\{0.75\left(5+\beta_{C B^{\prime}}\right)+0.5\left(\eta_{d^{\prime}}-\eta_{b}{ }^{\prime}\right)\right\} M_{y}\right]
\end{aligned}
$$


さらに荷重が増加して B 端もまた塑性ヒンジになる 場合には, 式 (57) において $M_{B C}=M_{P}=1.5 M_{y}$ とな り，式（58）の代りに次式をうる。

$$
\psi_{A C}=\frac{M_{y}}{0.5 r_{B C}{ }^{\prime}}\left[\eta_{d}{ }^{\prime}-\eta_{b}{ }^{\prime}-1.5\left(1-\beta_{\left.C^{\prime}{ }_{B}\right)}\right)\right]
$$

よって式（59）を式（56）に代大すれば, 崩壊荷重時 におけるたわみ $\delta_{C}=16.1 \times 10^{-2} M_{y} l^{2} / E I$ をえ, また式 (58) と式 (59) とを等置すれば, 崩壊荷重 $P_{P}=13.5$ $M_{y} / l$ をうる。

本例について, 塑性解析 ${ }^{12)} よ り$ 算定した荷重とたわみ との関係を図一21に併記したが, 崩壊荷重は当然合致 するも, たわみは一般に過小評価となっており, 崩壊荷 重時においては $\delta_{C}=11.1 \times 10^{-2} M_{y} l^{2} / E I$ で約 $30 \%$ 危 険側となることが認められる。

（4）図一23 (a) に示すごとき門型ラーメンの中央 $\mathrm{E}$ 点に, 集中荷重 $P=9.0 M_{y} / l$ が作用するときの曲げモ ーメント図および荷重点のたわみを求め, さらに崩壊荷 重時までを追跡する。ただし部材の断面は長方形 $(\kappa=3)$ とする。

まず弾性的に解けば,

$$
\begin{aligned}
& M_{A}=P l / 20=0.450 M_{y} \\
& M_{B}=P l / 10=0.900 M_{y} \\
& M_{E}=3 P l / 20=1.350 M_{y}
\end{aligned}
$$

となり, 中央 $\mathrm{E}$ 点の断面が弾性限を越えていることが わかる。したがって式 (45) などより塑性領域を算定 し, BC 材に $a_{i=1,2}=b_{i=1,2}=c_{2}=d_{2}=0$ として式 (43)

\begin{tabular}{c|c|c|c}
\multicolumn{4}{|c}{ 表一7 } \\
\hline$M_{A} / M_{y}$ & $M_{B} / M_{y}$ & $M_{E} / M_{y}$ & $c_{1} / l$ \\
\hline 0.450 & 0.900 & 1.350 & 0.089 \\
0.472 & 0.945 & 1.306 & 0.068 \\
0.474 & 0.949 & 1.301 & 0.067 \\
0.474 & 0.949 & 1.302 & 0.067 \\
\hline
\end{tabular}

を, BA 材に式 (42 d) を適用し， B 点における節点方 程式 $M_{B A}+M_{B C}=0$ に代入することにより，8. (1) (ii) の計算手法によりくり返し演算の結果 表一7をえ, 曲げモーメント図は 図一23 (b) のごとく求められる。 また荷重点 $\mathrm{E}$ のたわみは式 (9) と式 (14) とを適用 して $\delta_{E}=8.34 \times 10^{-1} M_{y} l^{2} / E I$ となる。

さらに崩壊荷重時まで追跡するには 9.（3）に準ずれ ばよく, 結果は 図一23 (c), (d), (e) に示すごとくな る。

\section{0. 結 語}

本論文は直線材鋼構造物 の 弾塑性挙動を解明するた め, その基礎としてまずェネルギー等置法により $M-\phi$ 曲線を $M-\phi$ 近似直線で置換したうえで, 補正エネルギ 一の実用式を弾性と同じ簡単な $M$ の 2 次式として誘導 し,ついで変分原理いわゆる Complementary Minimum Principle を適用して，弾塑性分野における補正エネル ギー法の実用化を試み, 各種静定ばりを対象とする弾塑 性解析を行なって, 厳密解あるいは塑性解析との比較検 討を行ない，その実用性を確認した。さらに不静定構造 物に対しては “弾塑性たわみ角式”を誘導し, もって弾

図-23

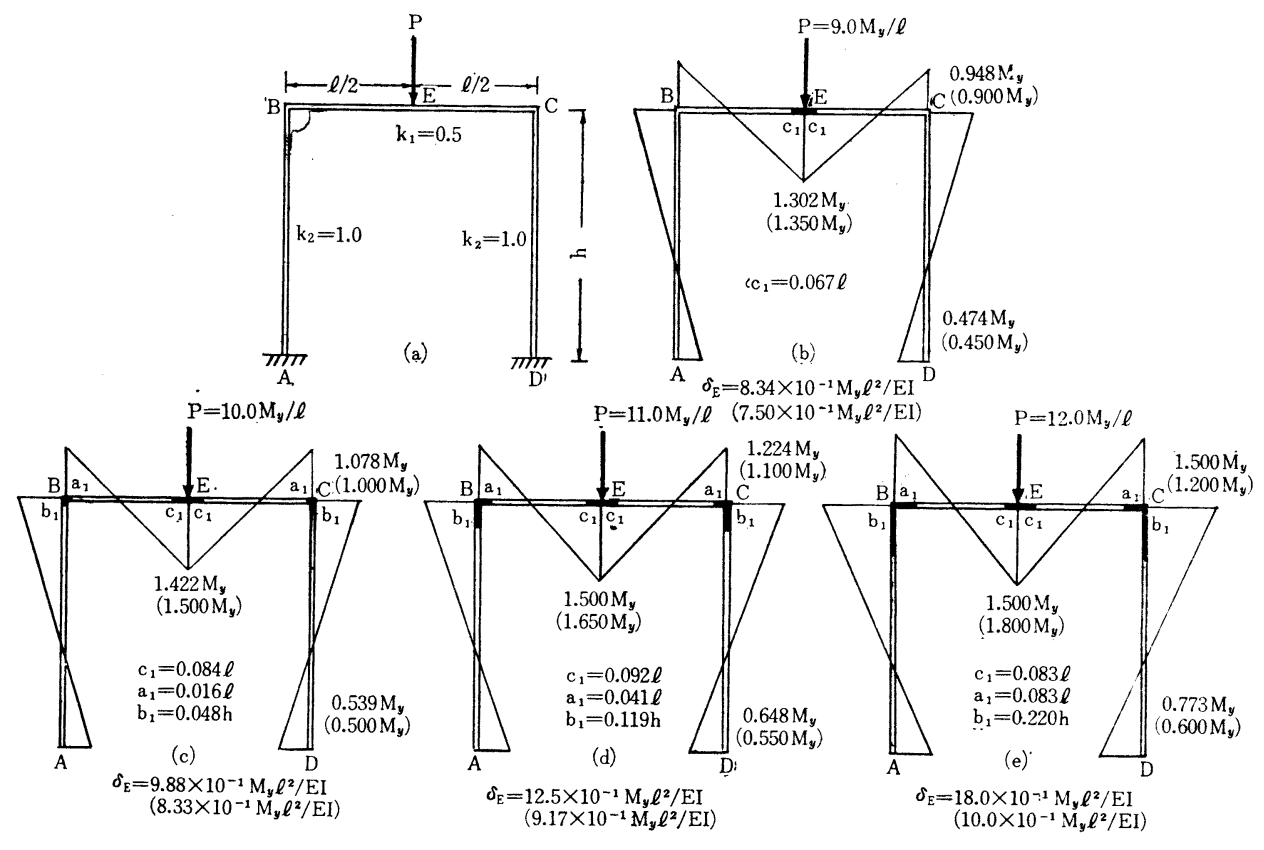

〔注〕一㹥塑性領域を，括弧内の数字は弾性材としての値を示す。 
性解析におけるたわみ角法に準ずる不静定構造物の弾塑 性解析を可能ならしめ, 実用解法としての $M-\phi$ 第 1 近 似直線の場合のたわみ角式諸係数の図表を作成して実用 に供しうるごとくした。

本法の特色を要約すればすでに各節でも指摘してきた ごとく, 第 1 に任意形状断面をもつ部材および任意荷重 を受ける部材に適用しうる普遍性, 第 2 に在来の塑性解 析を凌駕する高精度, 第 3 に慣用の弾性解析に準じた計 算手法の簡易性などである。また本法と同じ考察過程で 変断面部材をむ取り扱いうるのみならず，さらには弾塑 性領域における曲げモーメントと軸方向力を加味した補 正エネルギー式の誘導も可能となり，これより折線部材 やアーチ部材に対する弾塑性解析も行ないうるなど理論 の応用面での多様性が認められ，これが第 4 の特色を形 成し，アーチ部材に対する応用研究 ${ }^{13}$ が目下進行中であ る。

ラーメンの崩壊荷重は塑性解析によっても算出可能で あるが, 塑性領域の発生より崩壊に至る過程の応力およ びたわみを算定するためには, 当然本法によらねばなら ず，塑性解析の創始者といわれるVan Den Broek ${ }^{14)}$ "Any design theory that does not provide the means of determining the deformations corresponding to any given load up to the ultimate one is incomplete and questionable” と述べて弾塑性解析の重要性を早く より認めているが, 全く同感というべく本研究の価值も またそこにある。

\section{参 考 文 献}

1) Nadai, A. : Theory of Flow and Fractures of Solids, Engineering Societies Monographs, Vol. II, McGraw Hill, 1963.

2) Westergard, H.M. : On the Method of Complementary Energy and Its Application to Structures Stress beyond the Proportional Limit, to Buckling and
Vibrations, and to Suspension Bridges, Proc. A.S. C.E., Feb., 1941.

3) Brown, E.H. : The Energy Theorems of Structural Analysis, Engineering, Vol. 179, March, 1955.

4) Rawlings, B. : Energy Relationships in Plastic Steel Structures, Trans. A.S.C.E., Vol. 128, Part II, 1963.

5) Langhaar: Energe Method in Applied Mechanics, Wiley, 1962.

6) Gerstle, K.H. : Deflection of Structures in the Inelastic Range, Jour. of the Eng. Mech. Div., Proc. A.S.C.E., Vol. 83, July, 1957.

Gerstle, K.H. : Elastic-Plastic Deformation of Steel Structures, Jour. of the St. Div., Proc. A.S.C.E., Vol. 89, Feb., 1963.

7) Gerden, R.J.P. : Analysis for Moments and Deflections in the Elastic-Plastic Range, Proc. of Inst. of C.E., Vol. 16, June, 1960.

8) Yang, C.H., Knudsen, K.E., Weiskopf, W.H. 外 : Plastic Strength and Deflections of Continuocs Beams, Progress Report No. 9, The Welding Journal, Vol. 32, May, 1953.

9）山田孝一郎：暁角法形式による骨組の弾塑性解析とその 応用, 日本建築学会論文集 80 号, 81 号, 昭和 37 年 12 月, 昭和 38 年 1 月.

10）山猗・太田：塑性解析に拡張したエネルギー法, 第 19 回 土木学会年次学術講演会講演概要, 昭和 39 年 5 月.

山畸・太田・速水: $M-\phi$ 第 2 近似直線を用いた弾塑性補 足エネルギー法について, 第 20 回土木学会年次学術講演 会講演概要, 昭和 40 年 5 月.

11）山本善之：弾性・塑性, 朝倉書店, 1961.

12）たとえば Neal, B.G. : The Plastic Methods of Structral Analysis, Chapman \& Hall, London, 2 nd edition, 1963.

13）山猗・石川：連続アーチの弾塑性解析, 第 19 回土木学会 年次学術講演会講演概要, 昭和 39 年 5 月.

山崎・石川・黒木 : エネルギー法による固定アーチの弾 塑性解析, 第 21 回土木学会年次学術講演会講演概要, 昭 和 41 年 5 月.

14) J.A. Van den Broek : Theory of Limit Design, John Wiley and Sons, 1948.

(1965.12.1, 1966.1.31 受付) 